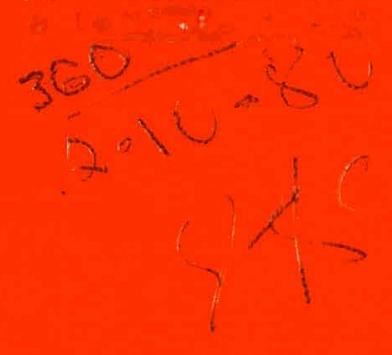<smiles>[Se]=[Sb]</smiles>

\title{
Baseline Study of U.S. Industry Solar Exports
}

\section{Final Report}

T. M. Jacobius

R. S. Levi

J. A. Bereny

IIT Research Institute

Chicago, Illinois

Solar Energy Information

Services, Inc.

San Mateo, California

Prepared Under Subcontract No.

AJ-0-8331-1
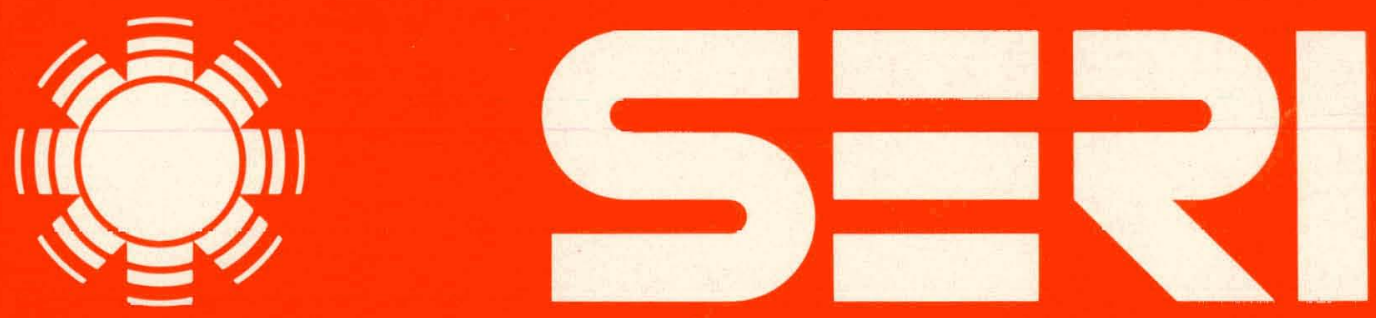

Solar Energy Research Institute

A Division of Midwest Research Institute

1617 Cole Boulevard

Golden, Colorado 80401

Operated for the

U.S. Department of Energy

under Contract No. EG-77-C-01-4042 


\section{DISCLAIMER}

This report was prepared as an account of work sponsored by an agency of the United States Government. Neither the United States Government nor any agency Thereof, nor any of their employees, makes any warranty, express or implied, or assumes any legal liability or responsibility for the accuracy, completeness, or usefulness of any information, apparatus, product, or process disclosed, or represents that its use would not infringe privately owned rights. Reference herein to any specific commercial product, process, or service by trade name, trademark, manufacturer, or otherwise does not necessarily constitute or imply its endorsement, recommendation, or favoring by the United States Government or any agency thereof. The views and opinions of authors expressed herein do not necessarily state or reflect those of the United States Government or any agency thereof. 


\section{DISCLAIMER}

Portions of this document may be illegible in electronic image products. Images are produced from the best available original document. 
Printed in the United States of America Available from:

National Technical Information Service U.S. Department of Commerce 5285 Port Royal Road Springfield, VA 22161 Price:

Microfiche $\$ 3.00$

Printed Copy $\$ 6.00$

\section{NOTICE}

This report was prepared as an account of work sponsored by the United States Government. Neither the United States nor the United States Department of Energy, nor any of their employees, nor any of their contractors, subcontractors, or their employees, makes any warranty, express or implied, or assumes any legal liability or responsibility for the accuracy, completeness or usefulness of any information, apparatus, product or process disclosed, or represents that its use would not infringe privately owned rights. 


\author{
BASELINE STUDY OF \\ U.S. INDUSTRY SOLAR \\ EXPORTS \\ FINAL REPORT
}

OCTOBER 1980

T. M. JACOBIUS

R. S. LEVI

J. A. BERENY

I IT RESEARCH INSTI IUTE

CHICAGO, ILLINOIS

SOLAR ENERGY INFORMATION

SERVICES, INC.

SAN MATEO, CALIFORNIA

PREPARED UNDER SUBCONTRACT

NU. AJT-0-8331-1

FOR THE

\title{
Solar Energy Research Institute
}

A Division of Midwest Research Institute

1617 Cole Boulevard

Golden, Colorado 80401

Prepared for the

U.S. Department of Energy

Contract No. EG-77-C-01-4042

SERI TECHNICAL MONITOR:

Peter ThOMPSON 


\section{THIS PAGE}

WAS INTENTIONALLY LEFT BLANK 
This study was performed by IIT Research Institute and Solar Energy Information Services under subcontract AJ-0-8331-1 for the International Division, Solar Energy Research Institute. The information summarized in this report represents a baseline assessment of exports in the emerging U.S. solar industry in calendar year 1979. The results are expected to be of value to various government and industry groups in developing a realistic program of export assistance and thereby encouraging the export of solar products and services wherever practical. We wish to express our gratitude to the program technical monitor, Mr. Peter Thompson, for his constructive support and direction throughout the program.

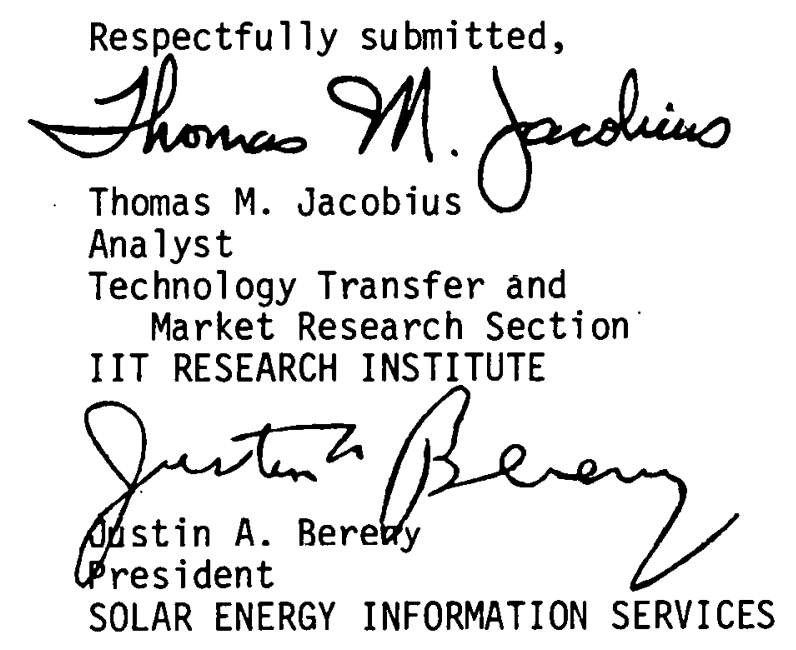

APPROVED:

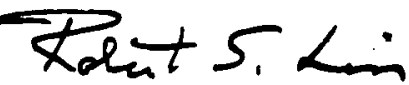

Robert S. Levi

Manager

Technology Transfer and

Market Research Section

IIT RESEARCH INSTITUTE 


\section{THIS PAGE \\ WAS INTENTIONALLY \\ LEFT BLANK}


1. INTRODUCTION

1.1 Purpose

1.2 Objectives

1.3 Approach

1.4 Scope

2. SOLAR INDUSTRY SEGMENT PROFILÉS 6

2.1 Photovoltaics 6

2.1.1 Overview 6

2.1.2 Aggregate Profile 8

2.1 .3 Export Mechanisms 10

2.1.4 Aggregate Buyer Profile 13

2.1 .5 Barriers to Export 16

2.2 Solar Heating and Cooling 20

2.1.1 Overview 20

2.2.2 Aggregate Profile - SHAC Active/Collectors 21

2.2.2.1 SHAC Collector Exporters 22

2.2.2.2 SHAC Collector Non-Exporters 23

2.2.3 Export Mechanisms - SHAC Active/Collectors 26

2.2.4 Aggregate Buyer Profile - SHAC Active/Collectors 28

2.2.5 Barriers to Export - SHAC Active/Collectors 31

2.2.6 SHAC-Active/Balance of System 32

2.2.6.1 Controls 33

2.2.6.2 Pumps 34

2.2.6.3 Storage 34

2.2.6.4 Other Components 35

$\begin{array}{lll}2.2 .7 \text { SHAC-Passive } & 35\end{array}$

2.3 Wind 36

2.3.1 Overview 36

2.3.2 Aggregate Profile 38

2.3.3 Export Mechanisms 42

2.3.4 Aggregate Buyer Profile 42

2.3.5 Barriers to Export 44

2.4 Solar Thermal Electric 44

2.5 Biomass 45

2.6 Low-Head Hydroelectric $\quad 46$

2.7 Ocean Thermal Energy Conversion (OTEC) 47 
TABLE OF CONTENTS (continued)

Section

Page

2.8 Supporting Products and Services

48

2.8.1 Architects/Engineers

48

2.8.2 Instrumentation

49

2.8.3 Other Services

50

3. SUMMARY OF SOLAR EXPORT SALES FOR 1979

4. RECOMMENDATIONS 56

4.1 U.S. Solar Industry Recommendations for Export Assistance

56

41.1 Information and Promotion Activities 56

4.1.2 Market Uevelopment Acitivitles: 57

4.1.3 Direct Purchase Activities 57

4.1.4 Competitive Response Activities 57

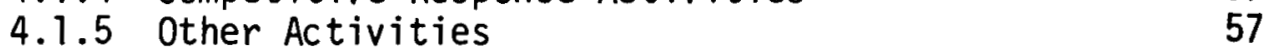

4.2 IITRI/SEIS Summary Recommendations for Export
Assistance

4.2.1 Targets of Export Assistance 58

4.2.2 Types of Export Assistance 59

4.2.2.1 Information and Promotion Activities $\quad 59$

4.2.2.2 Market Development Activities 61

4.2.2.3 0ther Activities 62

4.2.3 Organizing for Export Assistance 62

\begin{tabular}{ll} 
APPENDIX & 64 \\
\hline
\end{tabular}

A. LIST OF SOLAR INDUSTRY CONTACTS $\quad 65$

B. SELECTED BIBLIOGRAPHY 71 
$\underline{\text { Table }}$

Page

1979 U.S. Photovoltaic Industry Exports

2 Export Markets for U.S. Photovoltaic Products in 1979

3 Relative Contribution by Foreign Buying Segments to U.S. Photovoltaic Exports for 1979

41979 U.S. SHAC Collector Industry Exports 24

5 U.S. SHAC Collector Primary Export Distribution Channels 27

6 U.S. SHAC Collector Primary Export Promotion Techniques 27

7 Export Markets for U.S. SHAC Active Collectors in 1979

$8 \quad 1979$ U.S. Electrical Wind Energy Industry Exports by Size 40

$9 \quad 1979$ U.S. Wind Energy Industry Exports 41

10 Export Markets for U.S. Wind Energy Systems in 1979

111979 U.S. Solar Industry Exports 53

121979 U.S. Solar Company Concentrations of Export Sales in the Three Major Exporting Solar Segments 
THIS PAGE

WAS INTENTIONALLY

LEFT BLANK 


\section{EXECUTIVE SUMMARY}

The purpose of this study is to define the nature and extent of U.S. industry solar exports, with a "baseline" of calendar year 1979. IIT Research Institute (IITRI) and Solar Energy Information Services (SEIS) combined to conduct the study for the International Division of the Solar Energy Research Institute (SERI). The results present a detailed aggregate profile of U.S. solar export activity based on direct contact with all segments of the solar industry. Discussions were held with a carefully selected sample of 212 solar industry businesses, including 88 with export sales in 1979. The study focuses on each solar industry segment in terms of:

- The level of solar export sales in calendar year 1979

- The types of solar companies exporting and not exporting

- The techniques and strategies used to export successfully

- The foreign country markets, applications, and end-use purchasers with which U.S. solar companies have had experience

- The barriers to export which are presented by foreign country governments and companies, the U.S. Government, and the U.S. solar industry itself.

This information is then used to develop recommended actions for identifying realistic solar export goals and assistance measures which will encourage and enhance the export progress of U.S. solar companies wherever practical.

Summary of Solar Export Sales For 1979

As a result of our profiles of each solar industry segment, we have determined that the total level of solar industry exports in 1979 was $\$ 22.7$ million. The leading export segment was photovoltaics with $62 \%$ of total solar exports. followed by snlar heating and cooling $(22 \%)$, wind $(7 \%)$, solar thermal electric (5\%). and supporting products and services (4\%). This information is summarized in Table I on the following page. The study team has made every attempt to exclude export sales which resulted from U.S. Government sponsored demonstration projects, and so to indicate the current level of foreign private and public sector demand in commercial end-use applications and markets which represent foreign exchange for U.S. companies. 
THIS PAGE

WAS INTENTIONALLY

LEFT BLANK 


\section{Table I}

1979 U.S. SOLAR INDUSTRY EXPORTS

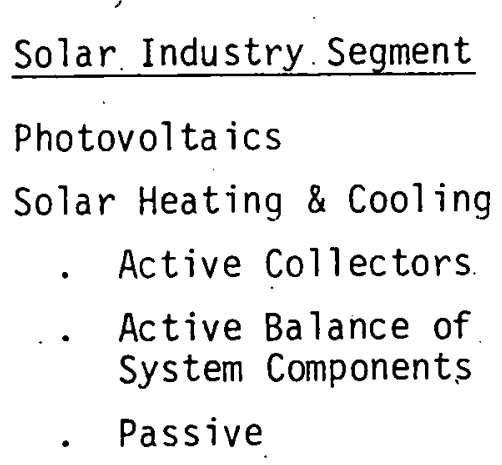

Export Sales

$(\$ 000,000)$

$\$ 14.0$

(SHAC)

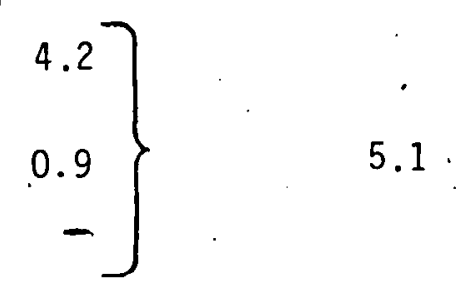

$\%$ of Total

Export Sales

$62 \%$

$22 \%$

1.5

$7 \%$

- Mechanical

Solar Thermal Electric

$\left.\begin{array}{l}1.2 \\ 0.3\end{array}\right\}$

1.5

1.1

$5 \%$

other Technologies

, Biomass

- Low-Head Hydroelectric

- Ocean Thermal Energy

Conversion (OTEC)

Supporting Products \& Services

- Architects/Engineers

- Instrumentation

$\left.\begin{array}{l}0.5 \\ 0.2 \\ 0.3\end{array}\right\}$

1.0

$4 \%$

TOTAL EXPORTS:

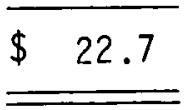

$100 \%$ 
A summary analysis of company concentrations of export business in major exporting segments is al so useful in understanding the nature of solar export activity in 1979. The findings suggest that in the three major exporting segments (photovoltaics, SHAC active collectors, and wind) there are an estimated total of 87 companies which had $\$ 19.7$ million in export sales in 1979. This represents about $25 \%$ of the total number of companies, and 13\% of the total sales volume (domestic and international), in these three solar segments. This data is presented in Table II.

Export barriers and concerns are certainly not restricted to the solar industry. The U.S. Department of Commerce estimates that of the 250,000 U.S. manufacturers, $10 \%$ are exporting. As indicated above, the level of export activity in the solar industry is considerably greater (i.e., ahnut. $25 \%$ of the solar companies in photovoltaics, SHAC active collectors, and wind exported in 1979) than the U.S. average of $10 \%$ in all industries. One conclusion that can be drawn from these observations is that, while U.S. solar exports in 1979 represented $\$ 22.7$ million vs. a 1978 estimate for total U.S. capital equipment exports (excluding automotive) of $\$ 46.5$ billion, the following factors combine to suggest the importance of developing a realistic, well-targeted, goal-directed international solar export effort:

- The significant level of solar export activity in 1979 , both in terms of the proportion of companies exporting as well as the proportion of sales exported,

- The potential value of renewable resources to export markets,

- The opportunity to represent appropriate U.S. solar industry exporting segments as a model for export assistance programs to serve other U.S. industries.

Within the three major exporting segments summarized in Table II, about $24 \%$ (21) of the 87 exporting companies accounted for $74 \%(\$ 14.5$ million) of the export sales. (The ?] companies represent $6 \%$ of the total number of 348 companies in the three segments.) The average export sales volume for the 21 companies was $\$ 690,000$ in 1979 .

Estimates were also made for the renaining solar industry segments with exports in 1979. There were approximately 38 additional exporting 
Table II

1979 U.S. SOLAR COMPANY CONCENTRATIONS OF EXPORT SALES

IN THE THREE MAJOR EXPORTING SOLAR SEGMENTS

\begin{tabular}{|c|c|c|c|c|c|c|c|c|c|c|}
\hline \multirow[b]{2}{*}{$\begin{array}{l}\text { Solar Industry } \\
\text { Segment }\end{array}$} & \multicolumn{2}{|c|}{ Summary Estimates } & \multicolumn{8}{|c|}{ Exporting Company Concentrations ${ }^{\star}$} \\
\hline & $\begin{array}{l}\text { Total \# } \\
\text { Companies } \\
\end{array}$ & $\begin{array}{l}\text { Total } \\
\text { Sales } \\
(\$ 000,000) \\
\end{array}$ & $\begin{array}{l}\text { Primary } \\
\text { Exporters }\end{array}$ & $\begin{array}{l}\text { Export } \\
\text { Sales } \\
(\$ 000,000)\end{array}$ & $\begin{array}{l}\text { Secondary } \\
\text { Exporters }\end{array}$ & $\begin{array}{l}\text { ExI } \\
\text { Sa } \\
(\$ 0\end{array}$ & $\begin{array}{l}\text { port } \\
\text { les } \\
00,000) \\
\end{array}$ & $\begin{array}{l}\text { Tota } 1 \\
\text { Exporters }\end{array}$ & $\begin{array}{l}\text { Tot } \\
\operatorname{Exp} \\
(\$ 0 \\
\end{array}$ & $\begin{array}{l}\text { al } \\
\text { orts } \\
00,000)\end{array}$ \\
\hline Photovoltaics & 19 & $\$ 31.0$ & 3 & $\$ 10.0$ & 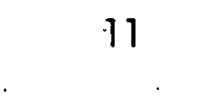 & $\$$ & 4.0 & 14 & $\$$ & 14.0 \\
\hline $\begin{array}{l}\text { SHAC Active } \\
\text { Collectors }\end{array}$ & 300 & 113.0 & 11 & 3.5 & 37 & & 0.7 & 48 & & 4.2 \\
\hline Wind & 29 & 8.5 & 7 & 1.0 & 18 & & 0.5 & 25 & & 1.5 \\
\hline TOTAL: & 348 & $\$ 152.5$ & 21 & $\$ 14.5$ & 66 & $\$$ & 5.2 & 87 & $\$$ & 19.7 \\
\hline & & & & Ali other & solar indus & $\operatorname{try}$ & segmen & $\therefore \sim 38$ & $\$$ & 3.0 \\
\hline & & & & & & & & $\sim 125$ & $\$$ & 22.7 \\
\hline
\end{tabular}

* Represents estimates of onty those companies who had export sales in 1979. 
companies accounting for the remaining $\$ 3.0$ million of export sales.

Thus in 1979 we estimate that 125 U.S. companies accounted for $\$ 22.7$ million of solar export sales, an average of $\$ 182,000$ per company.

Reviewing available data across all solar industry exporting segments, the "top ten" solar industry exporting companies represented about $\$ 16$ million of solar exports in $1979,70 \%$ of total solar exports. These ten companies range in size (i.e., total solar sales volume) from $\$ 1$ to 10 million. Six of the ten companies are in the photovoltaics segment, with the remaining four in SHAC active collectors, wind, and solar thermal electric. The remaining $\$ 6.7$ million of 1979 solar export sales was distributed across an estimated 115 companies in all the exporting segments.

Summary Recommendations for Export Assistance

The recommendations represent the key elements of a solar export assistance plan which requires the close support and coordination of both the U.S. solar industry and the U.S. Government. While it is true that solar companies with the resources and determination to export will do so, it is also apparent that companies trying to export can be more successful if realistic approaches are taken to alleviate barriers and create a more positive export environment. The recommendations are organized to respond to the needs of solar companies who are major exporters as well as those who to-date have had more limited exposure to exporting. The recommendations focus on the kinds of companies and industry segments that should be the targets of assistance, what assistance is appropriate, and how the assistance should be implemented, monitored, and controlled.

The overall thrust of an export assistance plan should be to stimulate and support specific solar industry segments and specific companies within the segments who offer the greatest opportunity for return on export assistance provided. This implies that as various solar industry segments emerge in the commercial marketplace, they should be targeted for similar types of assistance at levels considered to be appropriate. There are specific criteria which should be used to properly identify the solar industry segments and companies targeted for export àssistance. 
Each solar industry segment faces unique export barriers, so that different export assistance measures can be more important to one industry segment than another at any given time. However, there are also several broad areas where export assistance activities can serve a range of U.S. solar companies who are export-capable. The following types of assistance are recommended for providing support to the target industry segments and companies:

- Information and Promotion Activities

- Country-Specific Market Data for Solar Companies

- U.S. Solar Industry-Specific Product Data for Purchase Decision-Makers

- Market Development Activities

- International Applications Engineering Projects

- International Demonstration (i.e. Test Marketing) Projects

- Other Activities

- Purchaser Financing

- Tax Credit on Export Sales

- International Standards Development

- Etc.

Effectively organizing for solar export assistance requires both a means of coordinating all solar industry segments and U.S. Government solar export programs, as well as a clear set of goals for directing resources. A solar export advisory group is needed in order to provide a means of channeling solar industry opinion to key U.S. Government international. program representatives, and for such government representatives to formally and efficiently solicit the opinions from the various solar industry segments. Just as important, a detailed solar export assistance plan should be prepared for each target solar industry segment recommended by the solar export advisory group. Such plans would offer a more goal-oriented approach to successfully expanding the export market for U.S. solar products. 


\section{INTRODUCTION}

\subsection{Purpose}

This report documents the results of a baseline study of exports in the emerging U.S. solar energy industry for calendar year 1979. The basis for focusing on solar exports is to support the efforts of several groups both within the U.S. Government and in industry. The International Division of the Solar Energy Research Institute (SERI) has sponsored the study and expects to utilize the data and recommendations in order to provide reliable feedback to various government agencies and industry groups. The objective is to maximize wherever practical the export marketing of solar products and services.

Several U.S. Government agencies are interested in the results of this export study. The Office of International Programs in the Department of Energy (DOE) expects to utilize the data to help define what areas of solar technology should be supported and promoted more extensively for export, and what types of assistance are most appropriate to expand the solar export market. (This includes, for example, assistance and information to the solar industry regarding foreign trade shows.) The Department of Commerce (DOC), the International Trade Administration in particular, is interested in the results of this export study in order to (1) develop profiles of U.S. solar industry segments (available hardware and services, companies, current export market areas, etc.) for use by U.S. commercial attachés in foreign embassies, and (2) orient other DOC export programs and services to the needs of the solar industry.

The private sector as well has expressed a need for a more reliable base of information concerning the extent of exports in each solar industry segment. This information can be utilized to define the nature and extent of export support which various solar industry segments should be given, and to develop practical plans to respond to these needs. This study also serves as feedback to the U.S. Government from each solar industry segment regarding the unique export barriers and issues which influence export marketing strategies and performance. 
It is also anticipated that the results of this study will be useful to firms in other U.S. industries for making plans and identifying areas of mutual interest and opportunity for joint action with the U.S. solar industry. Foreign companies and governments may also find this study of value in (1) identifying potential U.S. joint venture partners in various solar industry segments, and (2) identifying U.S. companies who offer products and services which they are interested in purchasing.

\subsection{Objectives}

The primary objective of this baseline study was to estimate the level of solar industry exports in 1979; and to supplement this estimate with a set of actionable recommendations for increasing the export market penetration of the solar industry. A second major objective was to provide an aggregate export profile of the industry, indicating which industry segments were exporting in 1979, characterizing the exporting companies (in terms of relative size, ownership, etc.), identifying international market areas (countries, buyer segments, and applications) to which solar sales were made, and identifying export mechanisms (distribution and promotion methods, export marketing resources and strategies) used to reach the markets abroad. A third objective of the study was to obtain direct feedback from companies regarding (1) the barriers they were encountering in exporting, and (2) the actions the U.S. Government might take to remove export barriers and to more effectively support export efforts. In summary, this baseline study represents a "snapshot" of solar industry export activity in 1979, in terms of the volume of exports, the nature of export markets and marketing techniques, and the barriers to greater export sales.

\subsection{Approach}

The approach used to accomplish the program objectives was based on conventional industrial market research techniques. This included identifying and contacting key decision-makers in each solar industry segment. Based on our experience and judgement, coupled with the use of all available directories, listings, and data bases in the open literature,

at Solar Energy Information Services (SEIS), and at SERI, we focused at the outset on the product areas and the specific companies that were 
expected to represent the core of export sales activity in 1979. While we recognized that some solar industry segments were not likely to have had significant export sales due to their early state of commercialization, they were included in this study for purposes of completeness, and with the expectation that updates of this study would assess such segments.

The information contained in this report is based primarily on direct discussions with companies in the solar industry. A combination of phone and personal discussions was used in contacting the target companies in each solar industry segment. A total of 212 solar industry businesses were contacted during the course of the program. The 212 businesses are not a random sample, but were carefully selected to concentrate on the specific solar product areas and specific companies with the core of export sales in 1979. A final review indicates that 88 of the 212 businesses contacted had export sales in 1979. Additional discussions were held with suppliers to the solar industry, and with various association representatives. Refer toAppendix A for a list of companies contacted in each solar industry segment.

Our purpose was to focus on the supply side of the solar industry, and gather data which reflects the industry's current export experience and perceptions. We therefore did not contact end-users of the various technologies, and did not estimate the size of the potential export market.

A major emphasis of the study was to assess the level of commercial export sales (i.e., sales to foreign governments, corporations, or individuals) in the U.S. solar industry. Therefore, we made every attempt to exclude U.S. Government funded demonstration projects, which do not represent foreign exchange revenue coming into the United States.

Information gathered through our discussions with the industry was supplemented by an extensive review and continuous updating of secondary data. The secondary data was used to assure a reliable and complete estimate of export sales activity. Information from relevant reports, government hearings, workshops, etc., was reviewed to provide a basis for placing current industry responses in perspective and focus on significant export barriers. Refer to Appendix B for a bibliography of reports and articles which provided background support for this export study. 
The data presented in this export study has been aggregated in order to maintain the confidentiality of the company-specific information we obtained. We feel this has in no way compromised the objectives of the study. As a direct result of the cooperation we received both in the solar industry and in various government agencies, we feel confident that the information and estimates submitted in this report provide a reliable assessment of the status of solar industry exports in 1979.

\subsection{Scope}

The industry traces its roots to the activities of its professional association, the International Solar Energy Soclely (ISES) and its affiliated American Section, which existed long befure lie formulation of solar energy policy and programs at the national level, and several years before the establishment of the Solar Energy Industries Association (SEIA). When the U.S. Government promulgated its first National Solar Energy Plan (ERDA 49), it generally adhered to the technology classification that had evolved over the years within ISES. From this point forward (1973), a highly fragmented industry with many disparate elements emerged. Although the industry has grown rapidly since then, it continues to be highly fragmented, with the solar industry segments in various stages of development.

While the products of the industry have in common the direct. and indirect use of the sun's energy, many individuals perceive the industry to be more an agglomeration of technologies, products, and applications than an industry in the purest sense of the term. Various solar products have different levels of technology content, require dffferent marketing approaches, serve different types of. users and applications, and represent different levels of commercial sales activity. Pruriles of the companias ill. each product area (i.e., each solar industry seqment) reflect these differences. As an example, it is difficult. to visualize a few individuals manufacturing custom-made solar collectors in a very small facility being considered part of the same industry as a giant manufacturing company producing wind energy systems.

These realities of the heterogeneous structure of the industry emphasize the importance of recognizing the unique barriers to export 
and the unique types and levels of export experience of each solar industry segment. Thus an approach based on the current solar industry classification system was utilized to define the scope of this export study. These solar industry segments are presented in subsequent sections of this report in decreasing order of 1979 export sales as follows:

- Photovoltaics

- Solar Heating and Cooling (SHAC)

- Active Systems

- Collectors

- Balance of System

- Controls

- Pumps

- Storage

- Other Components

- Passive Systems

- Wind

- Solar Thermal Electric

- Other Technologies

- Biomass

- Low-Head Hydroelectric

- Ocean Thermal Energy Conversion (OTEC)

- Supporting Products and Services

- Architects/Engineers

- Instrumentation

- Other Services

Each solar industry segment is given an emphasis proportionate to its level of export activity in 1979 and its impact on total solar industry sales in 1979. All major exporting segments are characterized in terms of: an aggregate industry segment profile; export mechanisms used; international market areas, buyer segments and applications served; and barriers to greater export market penetration (including recommendations specific to each solar industry segment). The report concludes with a summary of 1979 solar industry export sales as well as a set of recommendations which represent: (1) direct feedback from the industry and (2) an overview analysis by the IITRI/SEIS program team. 


\section{SOLAR INDUSTRY SEGMENT PROFILES}

\subsection{Photovoltaics}

\section{1 .1 Overview}

Photovoltaics is the solar technology area that had the greatest dollar volume of exports during 1979. It is also most likely to be the technology that has the greatest export potential over the next five years. Current applications and economics indicate that the international marketplace is a viable one for development by photovoltaic (PV) firms and OEM/systems (Original Equipment Manufacture) firms integrating photovoltaics into their products. It is clear from discussions with the companies in the photovoltaic industry that the United States has the opportunity to maintain leadership in international markets despite anticipated competition. However, in order to successfuiliy respond to such an opportunity, many actions must be implemented by industry and government. The elements of an effective action program would include: (1) focusing on and understanding of specific target countries and applications which support the current marketing efforts of the photovoltaics industry; (2) development of effective financial incentives and financing mechanisms; (3) elimination of specific government barriers which pose serious obstacles to effective market penetration. These issues are addressed in the following sections of this discussion.

It appears that at the present time the international PV market is in such an early stage of development that there is enough business for everyone. But if consideration is not given to key problems relating to the ability of U.S. PV firms to market abroad (with the positive support of the U.S. Government where appropriate), then the U.S. PV industry may be preempted or seriously challenged in all markets, including eventually the U.S. domestic marketplace. Technological superiority in the manufacture of photovoltaic cells is not by itself sufficient insurance to sustain a credible and long-term market position. The U.S. PV industry must develop the systems capability and marketing finesse to address the needs of a growing market with field tested, reliable, readily available, serviceable products that potential users will feel confident enough to specify when addressing their energy needs. 
The perception that exports play a vital role in the developing PV industry has already been underscored by the development of an International Photovoltaic Program Plan. This plan, submitted by DOE to Congress in January, 1980, defines specific actions and timing emphasis which should "drive" the development of the international market for photovoltaics to increase energy self-sufficiency in developing countries, build PV production volume in the U.S., and gain valuable experience in which all will share, leading ultimately to the development of the U.S. market for grid-connected applications. (To date a comparable international plan has not been developed for any other branch of solar technology.)

Photovoltaics has benefited from years of technical development and cost reduction support through the U.S. space program. This fact has been documented in several previous reports and studies. Indeed, today, there remains, a viable market for photovoltaic cells for space applications, and a few of the photovoltaic companies continue to serve such a market. As the cost of cells has continued to drop, other cost-effective applications for photovoltaics have emerged. Specific examples include remote terrestrial applications for communications links, cathodic protection, navigational aids, etc. These application areas contribute to the commercial' terrestrial market of today, complemented by a market for terrestrial devices for DOE research and demonstration projects (e.g., "block" purchases, and the Federal Photovoltaic Utilization Plan \{FPUP\}), and in direct applications (Department of Defense $\{D O D\}$, U. S. Coast Guard, etc.) at government sites. Longer term cormercial prospects (i.e., 1985-2000) indicate a shift in emphasis from present applications to markets for centralized power as well as decentralized, grid-connected applications for residences and commercial/ industrial buildings. These markets, undoubtedly, represent the ultimate "pay-off" area for those firms who today are participating in PV applications and technology development. Thus the experience gained by development of the international market today will benefit firms in this segment of the solar industry far into the future.

Today, photovoltaics is the most viable solar export product area because of the real technical and economic benefits which can be realized in many remote applications with relatively low power requirements. Firms that are active in this segment of the industry are able, due to the high 
techrology content (and limited foreign competition), to profitably export cells, modules, and systems. But the unrealized potential in other applications is. much greater. Developing all of these markets and applications through U.S. systems engineering and U.S. OEM sales will help to retain the high balance of system (BOS) content and end-use load content as U.S. export sales revenue.

\subsubsection{Aggregate Profile}

The photovoltaics industry is fairly well defined, at the current stage of market development, with a limited number of companies offering commercial PV products. This is largely due to the high technology content of the product, the major capital equipment requirements which make it. difficult for newcomers to enter the field, and the early development stage of several promising cell configurations and manufacturing concepts. In 1979 there were about 20 U.S. companies engaged in manufacturing and/or assembly of PV cells, modules, and systems. (This excludes the companies supporting PV systems with batteries and other generic "balance of system" hardware.) There are a large number of additional companies engaged in research, development, and demonstration, both with and without government support. Our export study focuses on the approximately 20 companies with commercially available products in 1979 as well as a sample of eleven companies involved in photovoltaics research and development.

While PV cells, modules, and systcms arc used in both space and terrestrial applications, this export study considers only the companies and the sales which involve terrestrial markets. We also did not evaluate contract R\&D sales as an export area. Both space applications and contract R\&D represent a small proportion of total photovoltaic export activity, and therefore are not addressed in this report.

This report is based on discussions with 28 photovoltaic companies. There are eleven companies that. have nn PV product on the market, but are in various stages of research, development, and demonstration. Of the remaining 17 companies (representing about 1300 employees), 14 of.fer PV products for use in various space and terrestrial applications. Thirteen of the 14 companies offer products for terrestrial applications, with the remaining firm serving only space applications. This latter firm 
is thus excluded from subsequent discussion and analysis. The remaining three of 27 companies contacted are the systems and/or OEM firms who purchase PV cells and modules from the 13 U.S. companies described above, and integrate these components into systems for subsequent sale in terrestrial applications.

The group of 13 companies, offering PV cells, modules, and systems for sale in terrestrial applications, consist of eight firms that are privately held and five firms that are publicly owned. Four of the five are subsidiaries of major corporations. Eight of the 13 companies have 50 or less employees engaged in solar activities, while the remaining five have from 100 to 300 employees. All 13 companies are ten years old or less, with about half of them five years old or less.

All of the 13 companies indicated that they are engaged in exporting. But of these 13, there were eight companies that actually had export sales in 1979. Six of the eight companies who had exports have five years or less experience in exporting.

Thus, it is clear that while the industry and the terrestrial market are both fairly young, the export market has offered a viable opportunity almost from the start. There is virtually no other U.S. industry (except for nuclear power in its earlier history) in which exports has played such a significant role from the beginning. This offers great possibilities but also great risk for these small and infant companies in identifying, characterizing, and developing their market. And based on discussions with companies who have had exports, the export market is likely to increase as a percent of total sales - at least until the domestic U.S. gridconnected market begins to emerge. (Most photovoltaic companies indicated that the residential U.S. photovoltaic market is not likely to emerge until the late 1980's):

The 13 photovoltaic companies offering cells, modules, systems, and associated power conditioning equipment exported about $\$ 13$ million in 1979 for terrestrial applications. This represents approximately $50 \%$ of their total sales of $\$ 26$ million. Additional exports estimated at $\$ 1$ million were derived from U.S. system/OEM firms who integrated cells and modules into their products (e.g., navigational aids, cathodic protection 
devices, etc.) Total photovoltaic export sales of $\$ 14$ million accounts for about $62 \%$ of a 11 U.S. solar industry exports in 1979. Refer to Table 1 on the following page for a profile of U.S. photovoltaic industry exports in 1979 .

The remainder of this discussion will focus primarily on the experiences of the eight PV cell/module/systems companies who had export sales in 1979. They will be characterized in terms of their export mechanisms, the buyer segments and applications in which their products have been utilized, and the general consensus concerning barriers which are impeding export market development.

\subsubsection{Export Mechanisms}

Responsibility for export sales in PV companies lies with either a marketing department, the president, or other similar staff. In only one of the eight companies is there an international marketing manager; but in most cases total sales volume has not been large enough to justify such a person or department. Only two or three companies conduct internal market research studies to identify and profile target countries for export. The other companies recognize the value and need for such country-specific market intelligence, but cannot afford to gather it themselves. None is particularly interested in competitive profiles or current market size estimates since most feel there is enough business for everyone. The main need is for information about doing busiliess in various countries, identifying potential partners, purchasers and sources of financing, etc. (This is less true for the top three companies than for the others.)

Marketing channels utilized for export include direct personal contact, representatives, captive and independent distributors, and joint venture partners, and to a very limited degree export agents. The newness of the technology and related hardware places a great deal of emphas is on direcl contact, or distribution through knowledgeable distributors or venture partners. A great deal of education is required both in terms of the potential purchaser of PVs learning about the product, and the PV supplier learning about the needs of the potential purchaser. Export agents are generally inappropriate for PV export sales at the present stage of industry development, particularly if other channels are available to a company. 
Table 1

1979 U.S. PHOTOVOLTAIC INDUSTRY EXPORTS

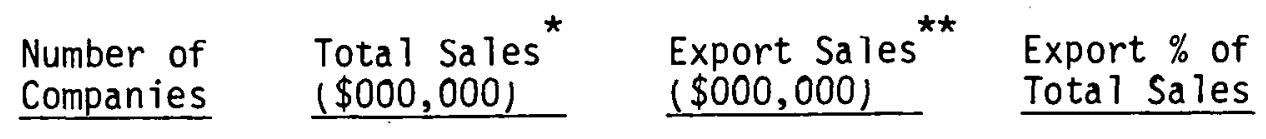

\begin{tabular}{|c|c|c|c|c|c|c|}
\hline \multirow{3}{*}{$\begin{array}{l}\text { Cells/ } \\
\text { Modules/ } \\
\text { Systems }\end{array}$} & 3 & $\$$ & & & 10 & $53 \%$ \\
\hline & 5 & & 5 & & 3 & $60 \%$ \\
\hline & 5 & & 2 & & - & - \\
\hline Subtotal: & 13 & $\$$ & 26 & $\$$ & 13 & $50 \%$ \\
\hline $\begin{array}{l}\text { Systems/OEM } \\
\text { Only }\end{array}$ & 6 & & 5 & & 1 & $20 \%$ \\
\hline TOTAL: & 19 & $\$$ & 31 & $\$$ & 14 & $45 \%$ \\
\hline
\end{tabular}

* Excludes space applications and contract R\&D, but includes government demonstration programs and "block" purchases.

** Excludes space applications, contract R\&D, and U.S. Government funded demonstration projects 
In a sense, systems companies or OEM firms can be considered to be channels for distributing PV products to end-users, contributing to the development of applications and markets. Sales of cells and modules are thereby stimulated, in addition to systems. This mechanism for export has not been utilized extensively to-date, since awareness of and familiarity with PV cells and modules capabilities has been low among U.S./OEM companies. Only in established terrestrial applications such as telecommunications, cathodic protection, navigational aids, etc., have OEM companies been significantly involved. Several of these are foreign companies based in Europe and Japan. As other applications emerge (primarily on the basis of economics), new OEM sectors will become export outlets for photovoltaics as well,

The 13 photovoltaic cell/module/system companies each have a different proportion of sales contributed by: (1) cell/module sales and (2) systems sales. This is a function of the stage of development of the firm, the corporate policy and market strategy of the firm, and the number and mix of employees. The top three companies a 11 emphasize system capability in addition to cell and module production, recognizing that experience in systems integration is key to addressing the needs of foreign markets, and developing these markets either directly or through sales to foreign UtMS.

Photovoltaic products are currently promoted by using forelgn advertising in approprlate lillerild livilal journals targcted to such industries as telecommunications, oil and gas distribution, etc. Half nf the eight companies with 1979 export sales do some advertising in foreign journals. Other mechanisms used include trade shows, exhibits, seminars, etc. Some of these have been sponsored by the Department of Commerce while others have not. (e.g., 3rd International Solar Energy Forum and Exhibition ENERGIA 80, Hambury, West Germany, November 18 20,1980; 1980 Photovoltaic Energy Conference, Cannes, France, October 27-31, 1980). The PV companies utilize these means of exposure to generate interest among potential purchasers and overseas partners or representatives. Generally, the diversity and extent of export promotion is a function of the size and resources of the PV company. Oniy four of the eight exporting companies have the resources to participate in foreign shows or travel 
abroad for promotional purposes as frequently as is considered necessary. The remaining four companies principally rely on their representatives or on foreign advertising to promote overseas sales. Nearly all thirteen PV companies offering products for sale in 1979 agree that the availability of a Department of Commerce catalog/product i iterature file in the Commercial Section of all U.S. embassies would be an important first step in creating greater awareness in foreign markets, and thus in assisting U.S. photovoltaics companies to increase exports.

The existing profile of the photovoltaic industry, and how it operates, is likely to dramatically change over the next five years as the volume of business multiplies. Some estimates indicate that the industry sales volume will multiply by more than tenfold by 1985, with the greatest growth anticipated in export markets. Exports could range as high as $90 \%$ of total sales by 1985. What is less certain is the impact foreign competition will have on United States PV systems sales. This is a strong function of the willingness and ability of U.S. firms, whether PV cell/ module/system companies or system/OEM companies, to develop the end-use markets in various countries; and the appropriate type and degree of commitment of the U.S. Government to support U.S. firms in this area.

\subsubsection{Aggregate Buyer Profile}

All companies with photovoltaic products regard the market for their products as international in scope. Sales in 1979 and previous years were made in all regions of the world. The top three PV cell/module/systems companies indicate that they have marketed to every continent. All companies declined to identify specific customers either in the U.S. or abroad, since they felt that such disclosures would affect their competitive advantage. Export sales by the eight U.S. PV companies have fallen into two broad categories: (1) systems sales to end-users in appropriate market areas, and (2) cell/module sales to foreign systems/OEM companies in the industrialized countries generally for transshipment to the lesser developed countries of the world.

In the case of the systems sales, end-use purchasers have been governments, utilities, railways, villages, and individual companies in either developing or industrialized countries. Many purchases, particularly 
in the oil-poor developing countries, involve subsidization of the buyer by a government or by an aid program.

In the case of cell/module sales, U.S. photovoltaic companies sell to other companies in industrialized countries (e.g., Japan, France, West Germany), who in turn are developing PV systems markets in developing countries. These foreign PV companies have the commitment and active support of their governments to, in many cases, give systems away in order to ga in experience and attempt to preempt the U.S. competition in developing countries. While such foreign PV company projects may not always be successful, they do serve to inhibit the foreign market development progress of U.S. companies. Refer to Table 2 for a representative list of current international markets for U.S. photovoltaic cells, modules, and systems.

The basis for selecting various end-use countries for market development is primarily dependent on the background and experience of the individuals in the PV company, or the established contacts of any supporting entities (i.e., joint venture partners, parent companies, etc.). The leading U.S. ce11/module exporters have entered into licensing agreements and/or joint ventures with European firms to provide an outlet for their products, and to have access to the experience base developed by their partners in end-use markets (e.g., developing countries). The other U.S. cell/module exporters recognize the importance of such arrangements, and several anticipate eventually doing the same, if not with foreign system/OEMs, then with U.S. system/OEMs whom they could tie-in with for export. Such arrangements have already been negotiated in some instances. This is particularly appropriate in the case of small stand-alone systems with their high volume and low unit cost and the attendant marketing expense of reaching a large number of potential users scattered around the world. This is most efficiently achieved by selling to or distributing through systems or OEM companies who have served the end-use markets for many years.

Based on our discussions with the 13 manufacturers of PV cells, modules and systems, and focusing in particular on the eight companies who have had export sales, it has been possible to determine the relative proportion of cells and modules sales vs. systems sales which were exported in 1979. 


\section{Table 2}

EXPORT MARKETS FOR U.S. PHOTOVOLTAIC PRODUCTS IN 1979

Export Market

Europe

Australasia:

Australia

New Guinea

New Zealand

Asia :

India

Korea

Japan

Pakistan

Mideast:

Kuwa it

Saudi Arabia

Africa:

$\mathrm{Mali}$

Niger

Latin America
$\%$ Frequency

of Mention

$25 \%$

19

19

16

12

9

$100 \%$ 
The statistics indicate the types of buyers currently being served by U.S. photovoltaics companies and their relative contribution to U.S. photovoltaic export purchases. As Table 3 shows, an estimated $45 \%$ ( $\$ 5.9$ million) of export dollar volume was purchased by foreign systems or OEM companies in 1979. The final products and systems resulting from such sales could eventually end up competing with that of U.S. photovoltaic companies or other U.S. OEMs in the end-use country markets. This competition makes it more difficult for the U.S. PV industry to gain maximum experience in systems design around end-use markets and applications.

It is clear from discussions with the photovoltaics industry that the greatest demand for photovoltaics in 1979 was for use in telecommunications systems for telemetry, microwave repeaters, etc. Virtually all current exporters of photovoltaics mentioned telecommunications as a major source of sales revenue. We estimate that at least two-thirds of commercial photovoltaics export sales go to this application. The remaining one-third of export sales is derived from other economically viable applications, including cathodic protection, navigational and signal aids, fence charging, consumer products, and water pumping.

While these applications all represent a large number of systems, the photovoltaic cell content per system is relatively small. Thus the selling cost per unit is generally higher than for centralized power or village electrification utilizing larger arrays of photovoltaics. The diverse nature of the applications also emphasizes the importance of developing OEMs as a distribution channel, particularly since these applications are expected to remain significant sources of revenue over the next five years. Ali application areas will grow in dollar volume. Water pumping applications are anticipated to experience the greatest percentage growth. The market will be further expanded over the next five years to encompass other applications such as village electrification, centralized power, and distributed industrial power.

\subsubsection{Barriers to Export}

Barriers to export sales are in the broadest sense a function of insufficient market awareness, insufficient resources to identify and develop markets and applications, insufficient use of outside resources 
Table 3

RELATIVE CONTRIBUTION BY FOREIGN BUYING SEGMENTS

TO U.S. PHOTOVOLTAIC EXPORTS FOR. 1979.

Ce11/Module/System

Company Concentration

3 companies with

$\$ 10.0$ million exports

5 companies with

$\$ 3.0$ million exports

8 companies with

$\$ 13.0$ million exports

*

To foreign systems/OEM companies in industrialized countries.

** To end-users for remote applications in both industrialized and developing countries.
Export Sales of

Cells, Modules*

$\$ 4.3$ million $(43 \%) \quad \$ 5.7$ million $(57 \%)$

Export SaTes

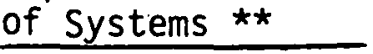

$\$ 5.9$ million $(45 \%) \quad \$ 7.1$ million $(55 \%)$

$\$ 1.6$ million $(52 \%)$. \$1.4 million (48\%) 
available for promoting and distributing to the market, and insufficient management, product development, or production resources to respond to demand. This is made infinitely more complex because each potential country market is unique. Virtually all photovoitaic companies agree there are several areas where significant export barriers exist. But to some degree export barriers are a function of the type and size of the company trying to export. Large companies, particularly those affiliated with major corporations, are less constricted than the small companies in terms of having ready access to communications, complying with U.S. Government forms and regulations, responding to proposals, traveling abroad, etc. This is true in most U.S. industries, but is accentuated in the case of photovoltaics by the considerable proportion of sales volume which is exported.

As indicated above, there are several areas where most photovoltaic companies agree that barriers to export exist. A main thread of concern is information/education. This takes several forms. The U.S. commercial attachés abroad are not knowledgeable about photovoltaics, either conceptually or in terms of hardware and suppliers. For those photovoltaic companies attempting to make contacts in various countries, either to' generate sales or identify partners, the commercial attachés have been of minimal value. This is generally recognized as being due to the relatively small proportion of U.S. exports which photovoltaics and the solar industry account for, and thus the proportion of time and effort which can be justified to devote to solar. The Department of Commerce has been informed of this concern, voiced by many solar product manufacturers at various export workshops and other forums over the last two years.

A lack of sufficient information and export education on the part of the photovoltaic companies themselves also represents a barrier to export. The companies generally agree that they need to develop a greater perception and working knowledge regarding the most promising export country markets. Country-specific market studies, which some of the larger companies have conducted independently, would serve to clarify the intricacies and nuances of doing business in various countries in terms of the culture, the politics, the marketing and technical service support infrastructure, in-place solar 
incentives and legislation, etc. This would help to reduce the uncertainties in exporting, and channel corporate resources more effectively.

The photovoltaic companies also indicate that there is a general lack of knowledge and awareness among other U.S. industries (i.e., potential "integrators" of photovoltaics into their products) concerning the current technical and economic advantages of photovoltaics. Addressing this issue, the NASA-Lewis Research Center sponsored a workshop in May, 1980 designed to educate and inform U.S. companies who would be potential outlets for photovoltaic module sales. While the program content was excellent, the attendance by U.S. companies who could potentially utilize photovoltaics was disappointing. The photovoltaics companies suggest that a concerted and well targeted effort should be made to educate potential U.S. systems and OEM companies (particularly those with current access to international markets) in order to better leverage the marketing resources of the PV companies and thereby expand both domestic and export markets.

Several photovoltaic companies point to the importance of international financial institutions in developing the export market. There is a need for a better informed financing sector regarding the types of systems which are commercially viable today. At the same time such institutions (e.g., the Export-Import Bank and World Bank) should have a solar allocation fund which encourages the financing of small systems.

There is also a concern among photovoltaic companies that they are at a distinct disadvantage in competing against such firms as RTC Philips and AEG Telefunken in terms of systems sales. This is due to the marketing support (e.g., high level contacts and negotiations) and financing support (e.g., outright gifts or significant subsidies) which foreign governments or consortia provide. While the U.S. is currently superior in terms of cell and module cost and quality (to the extent of supplying such components to the foreign systems competition), this does not translate into overall market supremecy unless photovoltaic systems marketing and financing assistance is given greater emphasis by the U.S. Government. The U.S. photovoltaics companies view very favorably both the U.S. Government "block" purchases of modules and the Federal Photovoltaic Utilization Program.(FPUP). These programs have helped place the U.S. photovoltaics companies on a 
rapid cost reduction curve (with increased volume leading to economies of scale) and provided experience in R\&D, design and production. Photovoltaic export marketing and financing assistance measures (recommended by the industry) should receive a similar emphasis by the U.S. Government as the logical next step to further market expansion and volume cost reduction.

\subsection{Solar Heating and Cooling}

\subsubsection{Overview}

The solar heating and cooling (SHAC) segment of the solar industry is comprised of more companies than any other segment. SHAC companies provide a wide range of products and services to meet a diverse assortmenl of applirations and user needs. This seqment in 1979 represents the second largest level of solar export sales, $\$ 5.1$ million (22\% of total solar exports). Nearly $85 \%$ of the SHAC export sales are in the "Active Collector" product area.

There are fundamental distinctions between photovoltaics and SHAC, which are crucial in understanding the considerable differences in the current and potential export market which each represents. These differences are a function of:(1) the technology, (2) the most appropriate export techniques, (3) the buyer segments, applications and economics, and (4) the barriers which inhibit a greater level of export activity.

The SHAC segment has been the focus of countless studies and reports which serve to provide a historical perspective on the development of this area. It is not the intent or purpose of this export study to provide such a historical overview. We instead encourage those who are unfamiliar with the SHAC area to contact the authors or the sponsor for a list of references. For purposes of this export study we have aggregated the data in the SHAC area as follows:

Active. SHAC Systems

- Collectors

- Low temperature (less than $43^{\circ} \mathrm{C}\left\{110^{\circ} \mathrm{F}\right\}$ ) collectors used primarily for swimming pool heating.

- Medium temperature $\left(43-82^{\circ} \mathrm{C}\{110-1800 \mathrm{~F}\}\right)$ collectors used primarily for domestic hot water (DHW), residential space heating, commercial hot water and space heating, agricultural and industrial process heating. 
- High temperature (greater than $82^{\circ} \mathrm{C}\left\{180^{\circ} \mathrm{F}\right\}$ ) collectors used primarily for commercial hot water and space heating, agricultural and industrial process heating.

- Balance of System

- Controls, Pumps, Storage, and Other Components used in various configurations for all collector applications described above, with component selection dependent on the nature of specific end-use requirements.

\section{Passive SHAC Systems}

- Design/Contracting Services (utilizing standard building products or custom-fabricated hardware) used primarily for hot water heating, and residential and commercial heating/cooling. While included here for completeness, these services are discussed in a separate section of the report under "Services".

- Pre-Fabricated Components or Sub-Systems used a lone for new and/or retrofit construction.

The following sub-sections present export profiles for Active and Passive. SHAC systems. Various products and services which support SHAC Active and Passive areas are presented in Section 2.8.

\subsubsection{Aggregate Profile - SHAC Active/Collectors}

A considerable amount of prior insight is required regarding the SHAC industry segment in order to properly evaluate the level of export sales in the Active Collector area - much more so than in photovoltaics or wind where there are fewer companies competing and thus a greater concentration of sales activity. In many respects a significant proportion of the SHAC Active Collector companies represent a cottage industry, sma 11 businesses operating on a regional basis with high labor content and low capital equipment or up-front financing requirements. Thus, in sampling the industry, an initial.screening was used to focus on the core of export activity. This screening was accomplished by reviewing all available directories (refer to Appendix B) and applying the judgement, observations, and perceptions gained through several years of monitoring the solar industry and its most active solar market areas.

The number of collector manufacturers is continually changing due to "ease of entry" and high mortality. It is therefore not surprising 
that there is no authoritative, definitive accounting of the total number of collector manufacturers. Best estimates are that 250-350 companies manufacture collectors and/or systems in the active SHAC segment. For purposes of this report we sha 11 consider 300 collector companies to constitute the collector segment. For one source of data concerning the number of collector companies refer to "Solar Collector Manufacturing Activity, July through December 1979", from the Energy Information Administration (EIA) of the Department of Energy. Our quantitative estimates of collector sales, domestic and export, were developed from primary data accumulated through discussions with selected collector companies, independent of the EIA report. The EIA report was used as one of many data sources during this export study, Iul as a primary sourcc of data.

As a result of the initial search and screening, approximately 50 companies were identified as the most likely to be involved in exporting and to collectively represent the greatest proportion of exporting activity. We contacted a total of 54 collector companies, of which 35 companies considered themselves to be exporters while the remaining 19 did not. Among the 35 exporters, seven had no solar export sales in 1979. The following export. profile was developed by conducting in-depth discussions with the exporters, and analyzing their experiences and market performance. We believe that it accurately reflects the level of export activity for the SHAC coller.tor segment in 1979.

\subsubsection{SHAC Collector Exporters}

Although all ririlis classified as collector manufacturers àre primarily engaged in the manufacture of this basic component, many of them also offer system design and consulting services. This is usually done to support the sales efforts for their collector products and associated hardware.

Many of the exportcrs are irivulved in solar technolngies other than active heating and cooling. They generally use identical or parallel distribution networks for these products. The volume of sales in the non-SHAC areas has been uniformly smal1. A few firms are developing biomass products, low-head hydroelectric products, photovoltaics products, or passive design services to complement their existing product line. 
A11 35 exporting companies have been in business less than ten years, with two-thirds in business five years or less. They manufacture low, medium, and high temperature collectors. All export sales activity has occurred within the last five years. It is interesting to note that about two-thirds of the exporting companies made export sales with in two years of their start. Thus the ease of entry into the collector business holds true as well in gaining early exposure to export markets, if only in response to unsolicited inquiries.

Among the 35 companies with solar collector exports, 20 are privately held while 15 are either publicly owned or wholly owned subsidiaries of public companies. These companies represent about 1,200 employees engaged in solar activities: 29 companies each with less than 50 employees, and six companies each with 100 to 200 employees.

Our discussions with the 35 exporting companies indicate that, in general, exporting is not a major contributor to total sales revenue. In no case were export sales found to exceed $10 \%$ of total sales. The 35 exporting collector companies which we contacted had aggregate export sales of about $\$ 4$ million, an estimated $6 \%$ of their total sales for 1979 . An additional $\$ 0.2$ million of export sales is estimated for the remaining 265 collector companies. Refer to Table 4 on the following page for a profile of U.S. SHAC collector industry exports in 1979.

\subsubsection{SHAC Collector Non-Exporters}

Of the 54 companies that were contacted, 19 are not currently pursuing export sales. In general, these firms do not view international sales as a real market opportunity. They consider it an endeavor that isn't worth the considerable effort and risk involved. It is probable that a great number of the estimated 246 companies not contacted also fall in this category. Therefore, the following feedback is valuable in understanding the current perceptions and business position of these companies in terms of the domestic and the international marketplace.

The explanations for having no interest in the export market varied... However, a common theme wa.s identified: penetration of the domestic market is difficult enough. Until they have a steady, well-defined market share in the U.S., most firms are unwilling to divert their management 
Table 4

1979 U.S. SHAC COLLECTOR INDUSTRY EXPORTS*

Number of

Companies

11

24

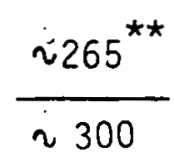

Total Sales

$\underline{(\$ 000,000)}$

$\$ 43$

22

$\frac{48}{\$ 113}$ \begin{tabular}{l} 
Export Sales \\
$(\$ 000,000)$ \\
\hline
\end{tabular}

$\$ 3.5$

0.5

$\frac{0.2}{\$ 4.2}$
Export \%

of Tota?

$8 \%$

$2 \%$

$\frac{<1 \%}{4 \%}$

*

These figures encompass low, medium, and high temperature collectors, but exclude absorber plates.

Includes companies with no export sales during 1979. We estimate that about 20 companies in this group had exports in 1979. 
time and resources to develop a foreign market. These companies generally agreed that by pursuing the domestic market, they are more likely to maximize the impact of a limited marketing budget. Several firms reported that their cash flow and production capability were just barely adequate to supply the domestic market, and that financing to alleviate this problem is not readily available.

High transportation costs and import duties, which place many U.S. collectors at a price disadvantage when compared to those produced in some foreign countries, are another factor that has kept some firms from exporting. These firms are also concerned about the problem of shipping because flat plate collectors are bulky to ship, and glass cover plates are subject to high breakage rates. Manufacturers of patented collectors are reluctant to export because the patents aren't protected in other countries. (Indeed, there are claims that collectors were purchased in some cases, only to be copied.) Finally, the smaller companies are avoiding the international market because it is a rather complicated environment for doing business; and they appreciate this fact. The extra forms required, and the additional risks involved, make exporting unattractive to a small business in a survival posture.

Despite the negative perceptions regarding exports that were mentioned above, about half of the companies that are not currently exporting have plans to do so in the next few years. Those who have such plans expect to utilize direct sales, export agents, and technology transfer (licensing) arrangements in approximately equal proportion. Although they don't actively pursue the international market today, most companies indicated that they are willing to respond to overseas requests.

In general, the companies with well established and reliable product lines felt that the domestic U.S. demand for their products was steadily increasing. Those with innovative or higher temperature collectors, however, expressed some disappointment. High production costs, high customer financing costs, and delays in federal solar tax credit legislation were among the reasons offered for experiencing lower than expected demand. 


\subsubsection{Export Mechanisms - SHAC Active/Collectors}

Due to the relatively small size of most exporting collector firms, and the relatively small percent of sales that is exported, in nearly all companies the export sales and marketing responsibility is in the hands of the president or sales manager. In the case of the larger corporations, the international activity is handled by an international division which represents all products the company offers. Most of the firms have one manufacturing plant, a few have two or three.

The exporting collector companies utilize a variety of approaches for distributing and promoting their products overseas. Distribution is accomplished through foreign licensees, independent distributorš, export agents; joint ventures and direct sales. For promotion, companies rely on direct personal selling, foreign advertising, trade shows, the Department of Commerce, and responses to unsolicited inquiries. Tables 5 and 6 on the following page indicate the relative frequency of use of these distribution and promotion mechanisms among the leading collector exporters.

Several factors were cited as being particularly advantageous in the solar export marketplace. Some firms are able to utilize a distribution network already in place for non-solar products. Others are able to utilize contacts developed by their parent companies. It is generally agreed that licensing the technology to foreign outlets is an effective means of gaining broad distribution without incurring high marketing expenses. Licensing can alleviate problems with foreign government restrictions and high import duties, which sometimes place U.S. products at an insurmountable price disadvantage.

Considerable care must be taken in selecting licensees and negotiating licensing agreements. Such arrangements have the advantage of providing "up-front" cash flow, but represent uncertainty in terms of bullding actual unit sales volume. This uncertainty is particularly apparent in the first few years of the agreement. Since collector exporting and current distribution approaches are relatively new activities, the extent to which licensing w111 be successful or preferred is nut yet clear.

Product design and packaging for export were also mentioned as being extremely important in order to respond to the differing technical 
Table 5

U.S. SHAC COLLECTOR PRIMARY EXPORT DISTRIBUTION CHANNELS

Distribution Channel

Independent Distributors

Direct

Licensing

Export Agents

Joint Ventures

Captive Distributors
$\%$ Frequency of Mention $30 \%$ 30 20 10 5 5

$100 \%$

Table 6

J.S. SHAC COLLECTOR PRIMARY EXPORT PROMOTION TECHNIQUES

Promotion Technique

Independent Distributors

Direct

Exhibits

Foreign Advertising

Unsolicited Inquiries ("Passive")

Department of Commerce Progralis
$\%$ Frequency: of Mention $27 \%$ 18 18 14 14 9

$100 \%$

* Based on responses of the top 11 SHAC collectur exporler's. 
requirements of foreign markets. Several companies claim that the superior quality and high efficiency of their collector offer a unique marketing advantage. Just as many other companies, however, regard U.S. collector technology as only marginally, if at all, superior to that of the foreign competition. This latter group of companies rely more on marketing techniques to develop an edge in export markets. They suggest that U.S. companies should anticipate new country markets (based on solar legislation being passed within the country, access to a marketing and service infrastructure, per capita income and energy consumption, etc.), and preempt the competition.

A few of the exporting companies use a modular design su lhal a "knocked down" shipping approach can be used tu reduce cusls arid minimize breakage. Installation and occasionally assembly, is handled by representatives in the country. The exception is large commercial or industrial projects, where the U.S. collector company often maintains control in order to assure proper installation and gain experience. In the case of low temperature unglazed plastic or rubber collectors, the low cost and low incidence of breakage in shipping is a distinct advantagne.

Most of the exporting collector companies reported participation in assistance programs of the Uepartment of Energy, Department of Cummerce, International Solar Energy Society, or the Solar Energy Industries Association. Generally it was telt that these organizattons should definitely play a more dynamic role in assisting companies to export by identifying specific foreign solar market opportunities, more effectively promoting solar products abroad, etc.

\subsubsection{Aggregate Buyer Profile - SHAC Active/Collectors}

Most of the exporting firms were marketing nationally, rather than just serving regional or local markets, prior to initiating export market activity. Europe is the most frequent destinaliun fur expurt sales, although some of the shipments to Europe may be transshjpped to other regions, such as the Mideast. Europe probably represents the largest volume end-use destination, followed by Southeast Asia, Central America, and Australia. In most cases companies speak of the great potential these areas offer in the years ahead, with most 1979 shipments characterized 
as very early market penetration or development of distributor/licensee networks. This indicates that the current period of solar export market development is critical in determining which export techniques are most appropriate for solar products and should be considered, and in determining which techniques are less suitable and should be avoided. Refer to Table 7 on the following page for an indication of the relative importance of various international markets to U.S. collector companies in 1979.

Most export sales in 1979 were for residential or commercial building applications, and a few collector sales were reported for use in industrial and agricultural projects. Some of the firms reported dealing with either the U.S. Government abroad or with foreign governments, although in many of these projects, government involvement was in the form of grants or demonstration projects. Solar collector companies are interested in U.S. Government involvement primarily to alleviate price differentials and negotiate favorable tariffs, not to control the identification or design of demonstration projects. Government markets do not appeal to some SHAC manufacturers because of the unconventional technical and financing requirements, the burden of documentation, and the investment of time required by such sales.

The greatest number of export applications were for residential domestic hot water (DHW) systems or swimming pool heating. DHW systems in particular represent an attractive market opportunity in Europe due to the wide use of expensive electric heating. Space heating is considerably less of an export opportunity at the present time than it is a domestic U.S. market opportunity. Several companies expect that space cooling will represent an attractive export application area, in the Mideast in particular, once the costs become more competitive, and the technology more reliable.

At the present time the leading U.S. SHAC companies are in a good market position viz a viz the foreign competition by having a rapidly growing domestic business base from which to expand to other country markets. Thus it presents a real opportunity for the SHAC companies who ( 1 ) have developed leadership positions in the U.S. market and (2) have the resources to monitor and explore export opportunities, 


\section{Table 7}

EXPORT MARKETS FOR U.S. SHAC ACTIVE COLLECTORS IN 1979*

Export Market

Europe:

Austria

Denmark

England

Germany

Holland

Italy

Norway

Sweden

Switzerland

Southeast Asia:

Hong Kong

Japan

Korea

Philippines

Taiwan

Central America:

Bahamas

Barbados

México

Australia:

Mideast:

Egypt

Saudia-Arabia

Turkey

South Ameica:

Chile

Canada :
\% Frequency

of Mention

$34 \%$

$30 \%$

$11 \%$

$11 \%$

$6 \%$

$6 \%$

$\frac{2 \%}{100 \%}$

* Based on experiences of the top 11 collector exporters in 1979. 
to aggressively capitalize on their expanding U.S. volume to penetrate new foreign markets as well. This is particularly important as foreign competitors begin to expand into the domestic U.S. market from such other active solar markets as Japan and Australia.

\subsubsection{Barriers to Export - SHAC Active/Collectors}

U.S. collector companies indicate that there are several export barriers which adversely affect their ability to compete effectively abroad. These are related to foreign competition, technical issues, and information requirements.

Foreign competition in SHAC systems is a significant factor in several respects. It is clear that foreign SHAC collector and system companies have considerable experience in their own countries in understanding and complying with government regulatory policies, and in utilizing the inplace marketing and product servicing infrastructure. U.S. collector companies generally have the same advantages over foreign companies in the U.S. market. In order to develop effective export strategies, it is necessary for U.S. companies to develop a detailed country-specific knowledge regarding who the foreign competition is, the quality and pricing of competitive products, the effect of foreign government subsidies, the number of annual solar system sales, etc.

There is a lack of agreement among U.S. SHAC collector companies regarding the export competitiveness of their products. Some collector companies claim they are at a price disadvantage in foreign countries due to high shipping costs and import duties. Other companies claim that foreign manufacturers are stressing low product cost rather than high quality and efficiency. On the opposite hand there are companies who indicate their products are competitively priced in foreign countries and that the product quality is not significantiy different from U.S. products.

U.S. companies feel strongly that the success of their export efforts is hampered by the lack of a cohesive set of international standards governing collector performance. Developing such standards, and developing a greater perception of technical requirements in various foreign markets, will go a long way toward enhançing the export posture of U.S. companies. 
At the current stage of market development there is an expressed need for other types of country-specific information. This includes identification of the countries that have solar legislation to support market development, the details of such legislation, availability of financing, availability of a trained work force and how to best tap it, the extent to which solar collectors can be economically justified, and the extent to which per capita income can provide the opportunity for an adequate sales volume. Other concerns of the SHAC collector companies involve more basic intricacies of exporting. Those areas mentioned include the selection of foreign partners and licensees, the process of making credit checks, overcoming the language/culture barrier, and obtaining reliahle and rnmplete data regarding solar insolation and technical product requirements.

The SHAC collector companies suggest that in order for them to export successfully, a greater awareness should be developed in prime foreign country markets about the off-the-shelf availability of U.S. collectors and system components. This includes educating U.S. commercial attachés, foreign government energy and trade ministries, foreign industries, and trade associations. U.S. companies feel that the experience they have had in beginning to develop the U.S. SHAC market should be promoted more positively through the U.S. Department of lommerce in forelgn countries. Many collector companies regard their trade association, the Solar Energy Industries Association, as ineffectual in representing their interests and needs to the government, other industries, other country markets and the general public concerning both domestic and export markets.

\subsubsection{SHAC-Active/Balance of System}

The principal products in this segment of the solar industry are pumps, contrcls, storage elements, and other components supporting SHACActive systems. During 1979, total export sales from this segment were on the order of $\$ 0.9 \mathrm{milli}$ ion, a relatively small share of total exports $(4 \%)$ compared to other segments of the solar industry. In the United States these components are generaliy purchased by a systems integrator either a contractor or system manufacturer - and subsequentiy sold as a complete system to end-users. This is analogous to the wholesale marketing infrastructure used to assemble, distribute and sell such conventional 
products as domestic hot water systems. Most balance of system components are sold to other U.S. companies, not exported for integration by foreign systems companies. Foreign firms generally rely on balance of system components available within their own country. Product availability, product servicing, voltage and frequency differences, etc., sometimes preclude foreign systems companies from considering U.S. components. For this reason there is generally significant export activity only where companies have worldwide distribution networks already in place, or have a technology which is superior to that offered by foreign companies. The following discussions highlight each of the balance of system areas and present specific export data wherever appropriate.

\subsubsection{Controls}

Approximately two dozen companies constitute the controls segment of SHAC technology. The companies vary in size from multi-national corporations to very small firms with less than ten employees. A few large companies, with an established product line of controls, expanded into the solar controls area. At the same time, a number of firms were formed by entrepreneurs who anticipated a substantial market opportunity. A few collector manufacturers also entered the controls market to insure the quality of their total systems. During the past six years there has been a proliferation of firms offering solar controls, despite the small size of the market. But with controls representing about $5 \%$ of total system selling price, as the demand for solar systems multiplies, the controls business represents an attractive market segment.

The 11 solar controls companies we contacted represent a balanced cross-section of the total solar controls industry. The study findings indicate that these companies account for the greatest proportion of total solar control sales in the United States, and also the greatest proportion of solar controls exports. We estimate that no more than $\$ 0.2$ million of solar controls were exported directly in 1979. Indirect exports of controls, as with other SHAC components, is accounted for in the SHAC collector export analysis. 


\subsubsection{Pumps}

Ten companies offering pumps for solar applications were contacted during the study. These ten companies represent the greatest proportion of solar pump sales activity. The level of export activity is rather insignificant. There are only a few solar pump companies in a position to export (represented by the ten which were interviewed) in terms of their financial strength and market position.

Most of the leading solar pump manufacturers are companies previously active in the pump industry. Solar industry applications are a logical area of market expansion, requiring little change in product specifications. They are generally subsidiaries of large American companies, or of overseas firms selling a broad assortment of pumps in the U.S. market. In the latter category, export policy is decided by the parent company, with export markets outside the U.S. served by either the U.S. subsidiary or the foreign parent.

It appears that there were no significant direct exports of solar pumps from U.S. manufacturers. In general, pump technology and the level of sophistication of firms competing in this market area around the world have limited any significant opportunity for exporting.

\subsubsection{3 storage}

The eight companies offering solar storage for domestic hot water or. space heating had negligible export sales in 1979. The nature of the product, specifically, its size and weight in relation to its cost, provides virtually no opportunity for direct export. A few of the companies have international distribution primarily through reyiulally located manufacturing plants around the world. If an appreciable market developed overseas, it is likely that solar storage elements would be supplied through these facilities. (In several foreign countries, domestic hot water heaters are based on a different design than in the U.S.) As in the case of controls and pumps, however, there is also an established supply from foreign storage component companies who generally support their solar systems companies. 


\subsubsection{Other Components}

This area represents an assortment of diverse products which support the systems integrators. This includes such products as coatings, sealants, heat transfer liquids, plastic sheets and films, valves, sensors, tubing, and absorber plates. Again, there is little opportunity for direct export except in the case of technology which is superior or highly competitive to that available abroad. This proves to be the case with sealants, heat transfer fluids, and films which are supplied through international distribution by major U.S. corporations. In addition the U.S. has a leading edge in black coatings for collectors which is licensed to foreign collector companies. The royalty income and sale of associated chemicals also represent export sales for this area of SHAC technology. Absorber plates represented a minimal level of export sales in 1979, and while it is conceivable that such products could be licensed.for manufacture abroad it is not likely to represent a significant export opportunity. As a result of discussions with about nine key firms representing all these component areas, it is estimated that the level of export sales for 1979 is about $\$ 0.9$ million.

\subsubsection{SHAC-Passive}

A fine distinction exists between what may be labeled a "passive solar product" and an energy conservation device. Energy conservation devices were not included in the scope of this study. Through custom and practice, those invoived in the passive solar product area have agreed on an acceptable definition as described below. The study team contacted manufacturers who represent themselves as passive solar product companies.

Passive solar healing and cooling is effected by efficient building design. Generally, it has not been considered to be a product-oriented field, inasmuch as most components used in passive solar buildings are conventional building materials. It appears, however, that this situation might change. One example is that some movable insulation and thermal storage products are beginning to be marketed as components of passive solar systems. Indeed, a "Passive Solar Products Association" has been formed as a division of the Canvas Products Association International. Moreover, DOE has rather recently awarded approximately $\$ 3$ million in 
grants for development of marketable, "stand-alone" passive solar products. But, to date, the export market for these types of products has been negligible.

Several reasons were given by manufacturers of the few existing passive products for not pursuing the export market. The most common reason was that companies manufacturing passive solar products tend to be small. Their resources are strained in pursuing the domestic market; and the domestic market for passive solar products is perceived to be underdeveloped. Another common reason for not exporting relates to the nature of passive products. Passive products can generally be groupen into two categnries: thermal storage and movable insulation. The marketable thermal storage products are principalily water cunlainers, which tend to be rather bulky and incur the disadvantage of "shipping air" (paying for the large volume of space that the product requires). However, a significant future export market is expected for phasechange-material storage devices.

Movable insulation products are more often imported than exported. They are either made of common materials and are easily replicated, or they are aimed at a technically sophisticated market that is only beginning to develop in the United States. Some traditional European movable insulation products have been imported for their high quality and proven durability. A promising future export market is also seen for thermally efficient glazing materials because they are a unique product of more advanced U.S. technology.

\subsection{Wind}

\subsubsection{Ovarview}

Over the past five years there has been a rebirth in the use of wind energy in respurise to increased energy costs. This rebirth has resulted from both private entrepreneurship and government funding for research, development, and demonstration. At the present time many wind energy companies are engaged in new product development and market testing in the United States in order to perfect various technologies and materials which can provide reliable and efficient power generation. In the wind industry as in most others, marketing and product development, with its inherently high up-front costs and risks, is best accomplished as "close to home" as 
possible. Most of the interviewed firms are currently in such a position. Therefore, unless previous foreign contacts or markets were already being developed, there was little interest or activity in wind energy product exports in 1979. Our study determined that about $\$ 1.5$ million of wind energy products were exported in 1979, representing $18 \%$ of total wind systems sales for that year.

As with other solar industry segments, wind energy is in a period of rapid flux. The period 1979-1980 could in retrospect represent a benchmark in the emergence of a viable wind energy market. The hardware being utilized, while posing some interesting problems and challenges, is generally a straightforward application of proven components and subsystems: Thus the technical and marketing barriers found in photovoltaics and SHAC commercialization are not as pronounced in the wind energy segment.

The main question which remains is the extent to which wind energy will be adopted as a practical supplement to conventional power generation, either distributed or centralized. The traditional market for wind energy has been for distributed remote applications. The economics readily justified such a market, and the rather basic mechanical technology is suited to such a market. Today's (1979) product sales are predominantly for these applications. This is true for both domestic and export sales. Wind machines which are being sold for these applications are generally in the range of $0.1-5 \mathrm{~kW}$

Considerable effort is now being devoted to develop and test large wind systems $(\sim \mathrm{MW})$. These products, were in the development and demonstration stage in 1979, and there were no domestic or export sales. These large scale systems will be suited for. (1) supplementing centralized power generation through the utility, or (2) for providing supplementary power generation for remote small towns or industrial plants. Large wind energy systems could have both a substantial domestic and export market. It is anticipated though, that the predominant market will be domestic.

The significance of wind as an energy supplement in the U.S. and abroad is that the technology, the economics, and to some extent the 
component supply infrastructure are all together more fully developed than for other solar alternatives. Thus, there are many who believe that the most substantial near-term solar energy contribution to total U.S. energy supply (excluding large-scale hydroelectric power) will come from wind energy. If this proves to be correct then experience developed in the United States over the next five years is also likely to support an export market. The extent of this future export market for small and large wind machines will to some degree be defined by the export issues, observations, and experiences of the wind energy segment in 1979.

\subsubsection{Aggregale Profile}

The wind energy industry In 1979 has considcrable vitality and near-term growth potential. Wind energy systems can be generically classified as electrical generating systems and mechanical systems. Each has unique applications and potential for both domestic and export markets.

Virtually all of the firms offering wind system products in 1979 are small companies. Their product's capacities generally range from 0.2 to $10 \mathrm{~kW}$. The U.S. wind energy system industry in 1979 consists of about 29 companies who manufacture and sell wind generators and/or sell complete systems. There are an additional eight companies, primarily large corporations, who are concentrating on the development of wind systems ranging in size from $15 \mathrm{~kW}$ to $1 \mathrm{MW}$.

Supporting the wind generator and systems companies are another 50-60 companies who provide components and associated hardware. This group of rompanies offers everything from inverters and alternators to batteries, towers, and anemometers. For the most part this group does not represent a significant export business, due either to the nature of the product (e.g., towers) or the competitive environment (i.e., components are purchased locally, within each country, by the foreign wirld systems companies.). In some cases wind energy components and systems are imported to the United States. However, this export study focuses on the market efforts of the U.S. Wind generatur/s.ystems companies, which reflect the total and export sales revenue of the U.S. wind energy industry. 
During the course of our study, contacts were made with 19 U.S. wind systems companies ( 15 electrical systems firms, 4 mechanical systems firms). Eleven companies indicated that they had export sales in 1979. Nearly all of the electrical wind system companies are 10 years old or less, while the mechanical wind system companies range in age from 10 to 50 years. Most export activity has taken place within the past five years.

A1l exports are either mechanical systems, or electrical systems in the capacity range of 0.2 - $5 \mathrm{~kW}$, with most less than $2 \mathrm{~kW}$. This size range appears to represent the most appropriate technology for export at the present time. (Refer to Table 8 on the following page for a profile of electrical wind system exports.) The types of applications (i.e., water pumping, remote ranch/farm power generation, etc.), and the competitive environment abroad in the larger size range ( $5-50 \mathrm{~kW})$ contribute to this situation. The emerging products in the larger sizes, $15 \mathrm{~kW}$ to $1 \mathrm{MW}$, will concentrate on a broader range of applications (particularly industrial) and more competitive marketing techniques and strategies in order to generate export sales.

All of the 19 wind systems companies selling commercial products are quite sma11, with generally no more than 30 employees. Nearly all of these companies are privately held. Only. two of the companies are affiliated with larger corporations. This profile reflects the nature of the business and the historically low opportunities for proprietary technology and production automation. This situation is likely to change as the market expands, and as major companies offering greater capacity machines enter the mar Our discussions with both electrical and mechanical wind energy systems companies indicate that 1979 exports contributed about $\$ 1.5 \mathrm{million}$ to a total sales of $\$ 8.5$ million, or about $18 \%$ of total sales. The greatest concentration of export sales was with seven electrical wind companies and seven mechanical wind companies accounting for over $90 \%$ of total export sales. Refer to Table 9 on the following page for a profile of U.S. Wind energy systems export activity in 1979. 


\section{Table 8}

1979 U.S. ELECTRICAL WIND ENERGY INDUSTRY EXPORTS BY SIZE

$\begin{aligned} & \begin{array}{l}\text { Capacity } \\ \text { Range }\end{array} \\ & \text { Less than } 2 \mathrm{~kW}\end{aligned}$
$\begin{aligned} & \text { Companies } \\ & 2-5 \mathrm{~kW}\end{aligned}$


Table 9

1979 U.S. WIND ENERGY INDUSTRY EXPORTS

\begin{tabular}{|c|c|c|c|}
\hline Number of Companie & $\begin{array}{l}\text { Total Sales } \\
(\$ 000,000)\end{array}$ & $\begin{array}{l}\text { Export Sa les } \\
(\$ 000,000)\end{array}$ & $\begin{array}{l}\text { Export } \% \\
\text { of Total }\end{array}$ \\
\hline
\end{tabular}

Electrical:

\begin{tabular}{ccccc}
7 & $\$ 3.0$ & $\$ 1.0$ & $33 \%$ \\
15 & 3.5 & 0.2 & $6 \%$ \\
$8($ R\&D on $1 y)$ & - & & - & - \\
\hline 30 & $\$ 6.5$ & $\$ 1.2$ & $18 \%$
\end{tabular}

Mechanical:

\begin{tabular}{clll}
$\frac{7}{37}$ & $\frac{\$ 2.0}{\$ 8.5}$ & $\frac{\$ 0.3}{\$ 1.5}$ & $=\frac{15 \%}{18 \%}$ \\
\hline & $\underline{=}$ & $=$
\end{tabular}

* Two companies offering both mechanical and electrical systems are double counted. 


\subsubsection{Export Mechanisms}

The relatively small export sales volume of wind systems (vs. photovoltaics and SHAC segments) is reflected in the type of organizational emphasis given to export marketing, including distribution and promotion. Most companies indicate that they respond to unsolicited inquiries generated either through advertising, directory listings or export agents. There is almost no active promotion through foreign trade shows or Department of Commerce programs due to the expense involved. A growing domestic U.S. wind systems market consumes a 11 the resources these companies currently have available. There is little left for more actively pursuing the export market. Several companies indicate that they are interested in investigating the potential for licensing or in-country manufacturing/ assembiy in potential export markets such as Mexico and South America. But most companies suggest that they are primarily concerned with developing a reliable and effective product, getting their production "up to speed", etc., in the United States before taking a more aggressive posture in export markets.

\subsubsection{Aggregate Buyer Profile}

There is considerable diversity in the types of export markets that U.S. wind energy companies have served. Such markets are obviously a function of climatic conditions (i.e. wind speed, terrain, and meteorological conditions.) It is not evident from discussions with U.S. manufacturers that they have a definitive perspective or solid information base concerning the most promising regions for their products in other countries, except in the broadest sense (i.e., South America, Africa, etc.). Refer to Table 10 on the following page for a summary of current wind export market areas, as indicated by the companies contacted.

The current purchasers of wind systems in other countries are split about 2:1 between the commercial and government sector. The size of a typical order is fairly small, only one or a few units, reflecting the types of purchases being made at this time for testing or for distributed use in remote locations. 


\section{Table 10}

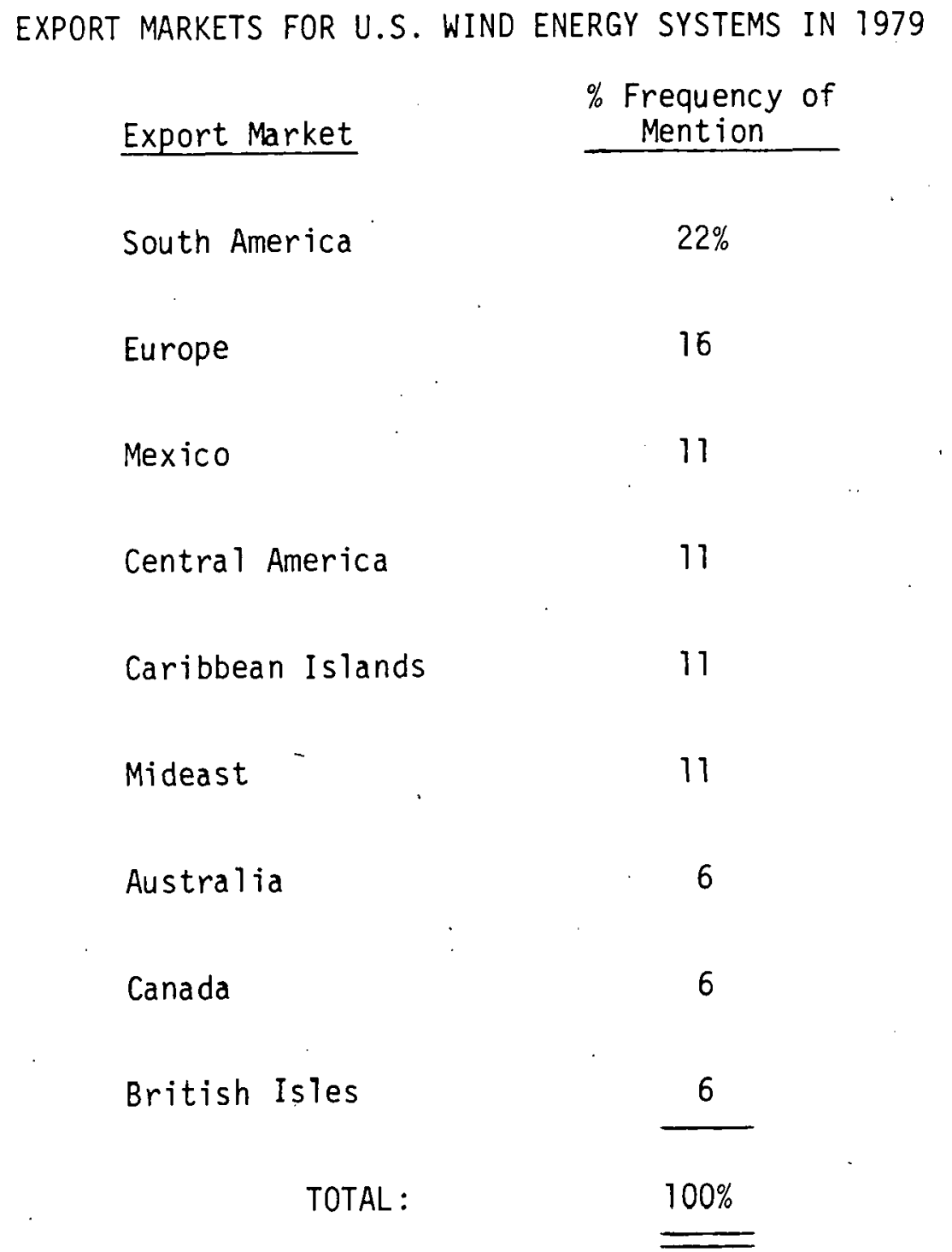


Applications of wind energy systems in export markets are identical to the U.S. market. The dominant use of mechanical wind systems is for water pumping. Electrical wind systems have been sold primarily as a supplement for farms and ranches to power agricultural or household load requirements. These remote applications will continue to be the primary area for smali-to-medium scale wind systems up to $10 \mathrm{~kW}$. Potential application areas include remotely located industrial plants. These potential users may find it economically justifiable to satisfy their energy needs with wind power. New generations of wind systems on the market in 1980 and beyond are likely to serve these needs in the capacity range above $10 \mathrm{~kW}$, Large $1 \mathrm{MW}$ machines could alsu cumpete in the morc lnad-demanding applications areas, as well as in the cenlralized systems which are being studied and experimented with by several U.S. utilities.

\subsubsection{Barriers to Export}

The wind export business is not at a level, in 1979, where barriers can be identified that have significantly inhibited sales. The main barriers are the modest financial resources and 1 imited management resources of the firms involved. U.S. wind companies do not have the production, marketing, or financial resources to venture abroad to any extent. It does nut appear prudent then for the U.S. Government to unduly encourage most of these companies to do so at the present time.

Among those who are exporting to some extent, there is an expressed need for more information concerning the export proqrams and policies of the U.S. Government, and more information about export opportunities in specific markets. Mure information regarding the potential buyers (and their technical requirements) and potential representatives or venture partners would alsu be helpful. Therc is also a need on the part of those who receive hundreds of unsolicited inquiries to be able tu respond adequately to each inquiry in order to assure that no potential sales opportunities are missed.

\subsection{Solar Thermal Electric}

The solar thermal electric segment of the solar industry is beginning to emerge as a viable commercial activity. Current emphasis, however, remains on field testing and demonstration in order to define levels of 
performance, and create awareness among potential users. In fact, in 1979 there were virtually no "commercial" sales anywhere in the world. The sales which did occur for the most part had a demonstration or field testing objective, but nevertheless represented foreign exchange for the U.S.

Export sales, which probably represented less than a dozen systems, are estimated for 1979 to have been $\$ 1.1$ million. While there are several firms in various stages of system development only two firms were found to have had export sales in 1979. This is likely to change dramatically in 1980 and beyond as commercial systems reach the market. Exports are expected to represent a significant opportunity for a variety of applications including: enhanced $0 i 1$ recovery, small community power, remote village power, agriculture, industrial process heat, and centralized power in the range of 1 to 10 MW capacity.

\subsection{Biomass}

The biomass segment of the solar industry is perhaps the most difficult to "pin down" and identify as such. A large percentage of the "value-added" to biomass energy conversion systems consists of standard industrial components assembled into a special configuration suitable for biomass applications. A great deal of the component hardware and technology is quite mature, and in many instances was developed overseas, where technical leadership still prevails.

A considerable amount of effort was expended during the course of the baseline study, attempting to profile this segment of the solar industry to see if any meaningful export statistics could be developed for base year 1979. The results of our investigation indicate that exports were negligible.

There is a great need to define the bounds of the biomass industry and to distinguish its products from those that have already been assigned Standard Industrial Classification codes. One case in point would be woodstoves. As a general statement, most woodstove manufacturers don't really consider themselves to be part of the solar energy industry. This line of reasoning was echoed by the Executive Director of the Wood Energy Institute who was contacted during the course of the study. His position 
is further reinforced by the fact that woodstoves have been assigned a separate SIC code. This situation is not unusual for other classes of "biomass" equipment, e.g., boilers, shredders, pelletizers, gasifiers, digesters, etc.

In the emerging area of alcohol fuels, no companies were identified as exporters during 1979. We did not identify any large-scale systems ( 15 million gallons and over) installed by American companies in overseas markets during 1979. U.S. Government program activities for this scale of production is concentrated in the Department of Energy.(DOE).

At the other end of the spectrum are small-scale systems for the on-site manufacture of alcohol (less than 15 million gallons). We were able to identify units that were only in the advanced development or prototype production stage. To the best of our knowledge, as of this writing, there are few (if any) systems available that can properly be considered "commercially available", and thus no commercial export sales were identified. U.S. Government program activities for this scale of production is concentrated in the Department of Agriculture and DOE.

\subsection{Low-Head Hydroelectric}

The low-head (small-scale) hydroelectric equipment market is comprised primarily of hydro-turbines, special controls, alternators, and any supporting equipment and construction services. Low-head hydroeleclric installations range from 100 to $1500 \mathrm{~kW}$ in size. There is believed to be a considerable opportunity for hydro-turbine manufacturers to adapt small U.S. dams to produce electric power. The Army rorps of Fngineers estimates that there are at least 5000 small dam sites which could conceivably generate new power. It is clear that the potential market is more severely determined by the site conditions than any other solar industry segment.

There are very few U.S. firms competing in this area, with small hydro-turbine systems a standard element in their product line. While this industry segment has no strong ties to other solar industry segments, there 'is a similar belief that greater coordination is required between government and industry in order to mobilize all alternate energy projects. 
The world in general probably offers a proportionate opportunity for small dam power generation. It is not apparent at the present time that this offers any significant export potential for U.S. companies. There are firms in other countries such as Finland and France who offer hydroelectric products in foreign markets and in the U.S. as well. In fact, at the present time the U.S. is more an importer of such equipment than an exporter. There was no significant export activity in low-head hydroelectric equipment in 1979.

\subsection{Ocean Thermal Energy Conversion (OTEC)}

There were no commercially available OTEC power plants in 1979. A11 activity was directed toward demonstration and systems development. The State of Hawaii helped sponsor a successful demonstration of a 50 kilowatt (15 kW net) Mini-OTEC prototype system in Hawaii in 1979. The U.S. Department of Energy has sponsored the development of OTEC-1, a 1 megawatt capacity plant, on-line in 1980. Subsequent DOE-sponsored demonstration efforts include plans for a 40 megawatt plant, which is expected to provide performance data with which to develop even larger scale plants. Companies active in this area believe that such demonstrations are valuable and necessary in order to develop a reliable, proven system, before any thought can be given to developing commercial or government markets.

Once such systems are proven technically and economically, OTEC plants are expected to be applied in appropriate island areas or off-shore from small communities or industrial facilities. Due to the high cost and complexity of subsystems, sales of such systems will take place through high level government and industry contacts. This industry segment does offer potential for export, if not in terms of all the hardware, at least in terms of systems integration services and/or technology transfer (1 icensing) agreements with foreign firms. But there is likely to be formidable foreign competition as well from France, Japan, and European consortia. 


\subsection{Supporting Products and Services}

\subsubsection{Architects/Engineers}

The architects/engineers ( $A / E$ ) segment of the solar industry can serve a key supporting role in developing the market for a variety of solar technologies, particularly solar heating and cooling (active and passive), photovoltaics, and solar thermal electric. The A/E and other contracting services serve as specifiers of, and therefore as important links in the distribution of solar products. It is thus important that for either large-scale or residential projects (independent of U.S. government funding) to be evaluated in terms of their solar potential, there must be sufficient awareness concerning the availability and reliability of such prōducts. Education and involvement of the A/E segment in regard to solar products is a crucial requirement in developing the marketing infrastructure which will help solar energy to attain the energy contribution levels (i.e., 20\% of total U.S. energy derived from solar) established for the year 2000 by the U.S. Government.

Nearly all solar projects to-date which involve architects/engineers have either been subsidized by the U.S. Government or have represented a public relations or promotional tool for the few corporations that have purchased solar systems. There has not yet emerged a significant, readily justified demand for large-scale engineered solar projects. ihis includes the use of solar systems to generate industrial process heat. At the other end of the spectrum, A/E groups who serve the residential or small commercial market have developed some experience in certain areas such as California or the Northeast, but again this has been limited.

The export market for U.S. architects/engineers services is similar to that described above, except on a smaller scale. Virtually all export projects (involving U.S. archllecls/enyineers) are largc scale applications. They are more oriented to consulting support thall lo direct systems design or installation. The majority of such projects to-date have generally involved either U.S., foreign government, or international agency funding; and have been either demunstrations or initial ventures into use of solar products. While there is a strong trend toward use of energy conservation techniques, SHAC-Passive has received relatively insignificant attention for large export projects. 
The A/E services generally have no comprehensive promotion or marketing program. Services contracts are obtained based on reputation, previous contacts, and responses to bid requests. This is true for both export and domestic sales.

The study team contacted 13 architects/engineers who have engaged in solar projects. Of the 13 companies, nine indicate that they have been involved in trying to export solar services, though generally on a small scale, or a one-time basis. The nature of the services exported was described in the previous paragraphs. Some of the larger A/E firms have only been involved with solar export activity to the extent of supporting other U.S. companies bidding on major U.S. government-funded demonstration projects in foreign countries.

Most of the companies contacted do not expect to pursue solar export contracts to any significant degree. They also do not view their solar experience as giving them a competitive edge in developing additional export business in the future. There is a general perception that U.S. exports of architects/engineers solar services is negligible compared to sale of such services in the U.S., which are also small and predominantly demonstration-oriented. The level of solar export sales for 1979 of architects/engineers services is estimated at $\$ 0.5 \mathrm{million}$.

\subsubsection{Instrumentation}

The solar instrumentation segment has been included under services, since it supports the research, demonstration, testing, and servicing elements of nearly all solar product areas. Solar instrumentation generally encompasses pyranometers (which measure total solar radiation), pyrheliometers (which measure direct solar radiation), anemometers, and other meteorological devices. Some of the solar instrumentation companies offer site analysis services as well. Most of these instruments have been on the market long before today's solar industry was born. Today, solar instrumentation is to a large extent purchased by governments, or organizations under contract to the government such as universities, research institutes, and companies.

Companies in the solar instrumentation area generally have few organizational or trade association ties to other solar industry segments. 
Many instrumentation companies are small (under $\$ 1$ million in total sales). The larger companies derive most of their sales from meteorological or scientific instrument application areas other than solar.

The primary market for U.S. companies is in the United States; and there is some import activity as well from Europe and Japan. The seven U.S. solar instrumentation companies we contacted did have some export sales. In total, exports represented about $\$ 0.2$ million, $10-15 \%$ of solar instrumentation sales. The U.S. companies compete all over the world, generally represented through catalogs, distributors, agents, and foreign or U.S. companies. These mechanisms generally make effective use of limited resources. Most of the site analysis services are provided inside the United States, and do not represent a significant export activity.

\subsubsection{Other Services}

This segment encompasses all remaining types of services which support the various solar industry segments. For the most part, these services are oriented toward providing education, information, and consulting. The services consist of publications and catalogs, seminars, solar curriculum development, training guides, video tape and films, market research studies, etc.

Solar export support services of this type are difficult to define, and do not represent a primary area of concern in developtrig expurl julicy and strategy. Thus they did not represent a major focus of our study efforts. However, based on contacts with several service firms of this type, and a working knowledge of exporting such services the study team is able to make a few summary observations.

Education, information, and consulting servicus serve the purposc, in this early stage of market development, of creating awareness and stimulating interest in various solar alternatives. This can be beneficial to individual solar product companies in these areas, as well as to the overall U.S. solar industry image in foreign markets. It would be informative to monitor such services in terms of the types of buyers and countries who purchase them. This could be an indicator of where solar research 
activity is occurring or where there is sufficient interest in solar to suggest export opportunities for U.S. solar products companies. Based on perceptions regarding this service segment, it is estimated that exports were on the order of $\$ 0.3$ million in 1979 . 


\section{SUMMARY OF SOLAR EXPORT SALES FOR 1979}

As a result of our profiles of each solar industry segment, we have determined that the total level of solar industry exports in, 1979 was $\$ 22.7$ million. The leading export segment was photovoltaics with $62 \%$ of total solar exports. followed by solar heating and cooling (22\%), wind $(7 \%)$, solar thermal electric $(5 \%)$. and supporting products and services $(4 \%)$. This information is summarized in Table 11 on the following page. The study team. has made every attempt to exclude export sales which resulted from U.S. Government sponsored demonstration projects, and so to indicate the current level of foreign private and public sector demand in commercial end-use applications and markets which represent foreign exchange for U.S. companies.

A summary analysis of company concentrations of export business in major exporting segments is al so useful in understanding the nature of solar export activity in 1979. The findings suggest that in the three major exporting segments (photovoltaics, SHAC active collectors, and wind) there are an estimated total of 87 companies which had $\$ 19.7$ million in export sales in 1979. This represents about $25 \%$ of the total number of companies, and $13 \%$ of the total sales volume (domestic and international), in these three solar segments. This data is presented in Table 12.

Export barriers and concerns arc cortainly not restricted to the solar industry. The U.S. Department of Commerce estimates that of the 250,000 U.S. manufacturers, $10 \%$ are exporting. As indicated above, the level of export activity in the solar industry is considerably greater (i.e., about $25 \%$ of the solar companies in photovoltaics, SHAC active collectors, and wind exported in 1979) than the U.S. average of $10 \%$ in a 11 industries. One conclusion that can be drawn from these observations is that, while II.S. solar exports in 1979 represented $\$ 22.7$ million vs. a 1978 estimate for total U.S. capital equipment exports (excluding automotive) of $\$ 46.5$ billion, the following factors combine to suggest the importance of developing a realistic, well-targeted, goal-directed international solar export effort: 


\section{Table 11}

1979 U.S. SOLAR INDUSTRY EXPORTS

Solar Industry Segment

Photovoltaics

Solar Heating \& Cooling (SHAC)

- Active Collectors

- Active Balance of System Components

- Passive
Export Sales

$(\$ 000,000)$

$\$ 14.0$

5.1

$22 \%$
$\%$ of Total

Export Sales

$62 \%$

$(2 \%$

$-$

Wind

- Electrical

- Mechanical

$\left.\begin{array}{l}1.2 \\ 0.3\end{array}\right\}$

1.5

$7 \%$

Solar Thermal Electric

1.1

$5 \%$

Other Technologies

- Biomass

- Low-Head Hydroelectric

- Ocean Thermal Energy Conversion (OTEC)

Supporting Products \& Services

- Architects/Engineers

$\left.\begin{array}{l}0.5 \\ 0.2 \\ 0.3\end{array}\right\}$

1.0

$4 \%$

- Instrumentation

- Other Services

TOTAL EXPORTS:

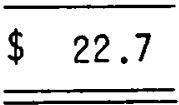

$100 \%$ 
Table 12

1979 U.S. SOLAR COMPANY CONCENTRATIONS OF EXPORT SALES IN THE THREE MA.JOR EXPORTING SOLAR SEGMENTS

\begin{tabular}{|c|c|c|c|c|c|c|c|c|c|c|c|c|}
\hline \multirow[b]{2}{*}{$\begin{array}{l}\text { Solar Industry } \\
\text { Segment }\end{array}$} & \multicolumn{3}{|c|}{ Summary Estimates } & \multicolumn{9}{|c|}{ Exporting Company Concentrations* } \\
\hline & \multirow{2}{*}{$\begin{array}{l}\text { Total \# } \\
\text { Companies } \\
19\end{array}$} & \multicolumn{2}{|c|}{$\begin{array}{l}\text { Total } \\
\text { Sales } \\
(\$ 000,000) \\
\end{array}$} & \multirow{2}{*}{$\begin{array}{l}\begin{array}{l}\text { Frimary } \\
\text { Expcrters }\end{array} \\
3\end{array}$} & \multicolumn{2}{|c|}{$\begin{array}{l}\text { Export } \\
\text { Sales } \\
(\$ 000,000) \\
\end{array}$} & \multirow{2}{*}{$\begin{array}{c}\text { Secondary } \\
\text { Exporters } \\
11\end{array}$} & \multicolumn{2}{|c|}{$\begin{array}{l}\text { Export } \\
\text { Sales } \\
\$ 000,000)\end{array}$} & \multirow{2}{*}{$\begin{array}{l}\text { Tota 1 } \\
\text { Exporters } \\
14\end{array}$} & \multicolumn{2}{|c|}{$\begin{array}{l}\text { Total } \\
\text { Exports } \\
(\$ 000,000)\end{array}$} \\
\hline Photovoltaics & & $\$$ & 31.0 & & $\$$ & 10.0 & &.$\$$ & 4.0 & & $\$$ & 14.0 \\
\hline $\begin{array}{l}\text { SHAC Active } \\
\text { Collectors }\end{array}$ & 300 & & 113.0 & 11 & & 3.5 & 37 & & 0.7 & 48 & & 4.2 \\
\hline Wind & 29 & & 8.5 & 7 & & 1.0 & 18 & & 0.5 & 25 & & 1.5 \\
\hline \multirow[t]{3}{*}{ TOTAL: } & 348 & $\$$ & 152.5 & 21 & & 14.5 & 66 & $\$$ & 5.2 & 87 & $\$$ & 19.7 \\
\hline & & & & & \multirow{2}{*}{\multicolumn{2}{|c|}{ Al1 other }} & solar irdus & try & segment & $: \sim 38$ & $\$$ & 3.0 \\
\hline & & & & & & & & & & $\sim 125$ & $\$$ & 22.7 \\
\hline
\end{tabular}

\footnotetext{
Represents estimates of cnly those companies who had export sales in 1979 .
} 
- The sianificant level of solar export activity in 1979 , both in terms of the proportion of companies exporting as well as the proportion of sales exported,

- The potential value of renewable resources to export markets,

- The opportunity to represent appropriate U.S. solar industry exporting segments as a model for export assistance programs to serve other U.S. industries.

Within the three major exporting segments summarized in Table 12 , about $24 \%$ (21) of the 87 exporting companies accounted for $74 \%(\$ 14.5$ million) of the export sales. (The 21 companies represent $6 \%$ of the total number of 348 companies in the three segments.) The average export sales volume for the 21 companies was $\$ 690,000$ in 1979 .

Estimates were also made for the remaining solar industry segments with exports in 1979. There were approximately 38 additional exporting companies accounting for the remaining $\$ 3.0 \mathrm{million}$ of export sales. Thus in 1979 we estimate that 125 U.S. companies accounted for $\$ 22.7$ million of solar export sales, an average of $\$ 182,000$ per company.

Reviewing available data across all solar industry exporting segments, the "top ten" solar industry exporting companies represented about $\$ 16$ million of solar exports in 1979 , $70 \%$ of total solar exports. These ten companies range in size (i.e., total solar sales volume) from $\$ 1$ to 10 million. Six of the ten companies are in the photovoltaics segment, with the remaining four in SHAC active collectors, wind, and solar thermal electric. The remaining $\$ 6.7$ million of 1979 solar expcrt sales was distributed across an estimated 115 companies in al1 the exporting segments. 


\section{RECOMMENDATIONS}

\subsection{U.S. Solar Industry Recommendations for Export Assistance}

The following set of recommendations represents feedback from various segments of the solar industry. In most cases these represent direct quotations from the decision-makers contacted within each company. These recommendations were used as a basis for identifying the elements of a positive plan of solar export assistance, for joint action by U.S. industry and the U.S. Government.

\subsubsection{Information and Promotion Activities}

- The government should sponsor studies which identify sperific, viable foreign country markets, and identify specific potential purchasers, licensees, or partners within the countries.

- The government should sponsor studies which help solar industry segments to become aware of the technical specifications their products should satisfy in order to compete abroad.

- The government should better identify and inform U.S. non-solar companies who currently export regarding available solar hardware for. which they could serve as export distribution channels.

- The government should better inform and educate the U.S. architects/ engineers and contracting services companies regarding available solar hardware, in order to increase the opportunity for integrating solar hardware into large-scile projects.

- The Department of Commerce commercial attachés should be better informed regarding what U.S. solar systems are available today.

- The solar industry should develop closer ties with established trade associations relating to solar (American Society of Heating, Refrigerating and Air Conditioning Engineers [ASHRAE\}, National Association of Home Builders, Offshore Technology Conference, etc.) in order ton promote solar as a credible energy alternative which is here today.

- The government should consolidate all avallable world climatological and geological data specific to each solar industry segment in order to facilitate product development, marketing strategies, and system destgn which will be targeted to vinhle end-use markets.

- The government should limit as much as possible the ready access to technical and market da.ta by foreign governments and companies.

- The government should underwrite the cost of attending foreign exhibits for companies with specific qualifications to be able to export. 
- The Solar Energy Industries Association (SEIA) should have a more effective lobbying effort as its primary role, with equal representation by all solar technologies.

- A more effective communication link should be established between the government and specific individuals representing all solar industry segments.

\subsubsection{Market Development Activities}

- The government should in general sponsor more demonstration projects, both in the U.S. and abroad, which contribute to the development of viable commercial markets.

- The demonstration projects should be designed to use the most appropriate and available technology, for the most appropriate applications in the most appropriate countries to a much greater extent than has been done to-date.

- The government should better distribute available demonstration project awards between small and large companies.

- While AID countries represent some opportunity for utilization of U.S. solar energy products, these countries should by no means receive a disproportionate share of U.S. solar energy market development or demonstration support by the U.S. Government.

\subsubsection{Direct Purchase Activities}

- The government should continue to purchase developing solar technology products (e.g., photovoltaics, solar thermal electric) so that U.S. solar companies benefit in terms of product development, production experience, and cost reduction.

- The government should purchase some of the components and systems on the basis of not only laboratory performance and low cost, but reliability and field performance as well.

\subsubsection{Competitive Response Activities}

- The government should negotiate more favorable import tariffs in countries targeted for solar energy export sales.

- The government should provide solar products with more favorable shipping rates.

- The government should provide a more favorable tax treatment for Americans based abroad who work for solar companies.

- Foreign firms should be limited in their ability to bid on U.S. Government projects.

\subsubsection{Other Activities}

- The government should provide a tax credit to a company as a percent of its export sales of solar products and services. 
- The government should assist in developing international standards of performance for solar energy products.

- The government should provide the Export-Import Bank with more financing specifically dedicated to solar products; and should lower the minimum dollarlevel of a sale to accommodate smaller solar system sales.

- The government should minimize its creation of grand-plans for solar energy and should maximize its dollar commitment to programs already in place.

\subsection{IITRI/SEIS Summary Recommendations for Export Assistance}

The recommendations outlined below represent a summary analysis by the IITRI/SEIS study team, utilizing constructive industry comments to identify the key elements of an export assistance plan. This plan in order to succeed requires the close support and coordination of both the U.S. solar industry and the U.S. Government. While it is true that solar companies with the resources and determination to export will do so, it is also apparent that companies trying to export can be more successful if realistic approaches are taken to alleviate barriers and create a more positive export environment. The following recommendations are organized to respond to the needs of solar companies who are major exporters as well as those who to-date have had more limited exposure to exporting. The recommendations focus on:(1) the kind of companies and industry segments that should be the targets of assistance, (2) what assistance is appropriate, (3) and how the assistance should be implemented, monitored and controlled.

\subsubsection{Targets of Export Assistance}

The overall thrust of an export assistance plan should be to stimulate and support specific solar industry segments and specific companies within the segments who offer the greatest opportunity for return on export assistance provided. This implies that as various solar industry segments emerge in the commerclal marketplace, they should te targeted for similar types of assistance at levels considered to be appropriate. Criteria for targeting export assistance should at the minimum be based on the following profile:

- The U.S. Government should encourage only those companies to export who have adequate management and financing capabilities. 
- Solar industry companies targeted for export assistance should be selected on the basis of at least two of the following:

- Experience in using Department of Commerce and other government export services

- Experience in exporting

- A total annual solar sales of at least $\$ 1$ million.

- Industry segments should be targeted for immediate export assistance that either:

- Have a demonstrated performance in exporting at least $10 \%$ of total solar dollar sales which serve "commercial" end-use applications (e.g., photovoltaics).

- Have the potential of significantly penetrating international markets beyond current levels within 3-5 years (e.g., SHAC Active Collectors).

\subsubsection{Types of Export Assistance}

Each solar industry segment faces some unique export barriers, so that different export assistance measures can be more important to one industry segment than another at any given time. However, there are also several broad areas where export assistance activities can serve a range of U.S. solar companies who are export-capable. The following types of assistance are recommended for providing support to the target industry segments and companies identified in Section 4.2.1.

\subsubsection{Information and Promotion Activities}

- Country-Specific Market Data for Solar Companies

It is extremely important to recognize that each solar industry technology has a unique set of countries for which it is most suited. Therefore, it is essential for a solar industry segment, in developing an export market, to identify. specific countries which overall represent the best potential for initial penetration. The large companies are able to develop much of this information themselves, but many smaller exporting companies do not have the resources to do so.

A realistic starting point, for selecting countries to study and promote, is to identify where companies are exporting or beginning to export today, and from where inquiries are received. A pragmatic 
assessment must be conducted beyond the general country statistics which are readily available, and more to the point of analyzing in detail the specific aspects of a country which pertain to successfully importing solar products from a specific solar industry segment. For a given solar technology, countries considered for initial market development should have a favorable profile in terms of:

- Existence of an appropriate marketing infrastructure

- Existence of an appropriate manufacturing/assembly/ service infrastructure

- Extent of favorable foreign government support of solar through specitic policies or legislation

- Avallablilty of financing for purchasers

- Potential for licensing or local manufacture/assembly

- Degree of political and economic stability

- Historical receptivity to U.S. industries

- Extent and nature of foreign competition

- Specific energy load requirements and types

- Energy consumption levels and forecasts of demand (e.g., per capita)

- Relative potential of each country in terms of the number of installations, for specific types of solar systems

- U.S. Solar Industry-Specific Product Data for Purchase Decision. Makers

Foreign decision-makers in both the private and public sector should be better informed regarding available U.S. solar products and services. One Important means to accomplish this is through the various U.S. Government agency persnnnel (e.g., DnC. commercial attachés) who require a more comprehensive and up-to-date base of solar product information. This could be achieved by developing a solar product/ service catalog file of available hardware, services, and company contacts. It should be the responsibility of exporting companies to assure that their catalogs, etc., are supplied to the DOC offices.

U.S. non-solar industries should be better educated regarding the solar technologies available today. This would encompass potential. 
users/purchasers of solar products as well as potential "integrators" of solar components and systems into their original equipment (OEM) products: A dynamic means of accomplishing this (as opposed to compiling paper reports, etc:) could be through a series of regional seminars directed at a very carefully selected cross-section of U.S. non-solar industries. Such seminars should have a predominantly industry orientation (both solar industry and non-solar industry participants), with a focus on commercial markets and applications experience.

\subsubsection{Market Development Activities}

- International Applications Engineering Projects

Solar companies should be provided an investment-type tax credit for product development directed to specific applications engineering (adaptive engineering) projects for international markets. Companies could submit unsolicited proposals defining the target country market, the application, the specific potential user, the technology, and the potential for broad-scale adoption. The credit would apply to all incurred expenses for the project, including hardware modification, marketing effort and travel costs.

- International Demonstration (i.e., Test Marketing) Projects

Demonstration projects should be conceived specifically to involve U.S. companies of all sizes in planning, design, installation, and follow-up. These projects should be carefully considered in terms of:

- appropriate countries

- appropriate applications and users

- appropriate technologies

- appropriate follow-through promotion

Each country targeted for such demonstration projects should be selected on the basis of:

- the level of current U.S. solar industry experience and/or inquiries from the country 
- existence of a sufficient and appropriate marketing/technical service infrastructure, which will permit direct extrapolation of experience and contacts gained through the demonstration to other commercial opportunities in the country

- the findings of comprehensive country-specific market studies which identify a favorable solar sales potential and solar business environment in terms of solar legislation, etc. (See Section 4.2.2.1 "Information and Promotion Activities")

\subsubsection{Other Activities}

Additional recommendations for assistance which are considered important in order to maximize the opportunity to export and the success of exporting consist of:

- Foreign trade exhibit subsidies to export-capable U.S. solar companies.

- Sufficient financing support of interested purchasers through the Export-Import Bank and other sources, with a reduced minimum to permit financing of smaller projects.

- Direct tax credit of $10-20 \%$ of export sales dollars to solar companies

- U.S. Government liaison between target solar industry export segments and foreign governments whose countries represent export sales opportunities.

- U.S. Government negotiation of more favorable import tariffs to identified target countries.

- U.S. Government coordination of international solar product standards deve lopment.

\subsubsection{Organizing tor Export Ass1stance}

- Solar Export Advisory Group

A solar export advisory group is needed in order to provide a means of channeling solar industry opinion to key U.S. Government internationa 1 program representatives, and for such governmenl representatives to formally and efficiently solicit the opinions from the various solar industry segrients. Such a communications vehicle would serve to implement, control, and monitor various export assitance measures. There is clearly a need for a focused communications mechanism between the solar industry and government if the export assistance activities outlined in the previous pages are to be successful. This group should have the responsibility 
for taking the initiative and formulating recommended assistance programs, and targeting them to appropriate solar industry segments and companies.

A key aspect of organizing such an advisory group should be the equal representation of the solar industry and government. All solar industry segments should be fairly represented. Individuals should be appointed to the advisory group who, as a minimum, represent solar exporting companies and have the clear endorsement of the companies competing in the segment. The U.S. Government representatives should be drawn at the minimum from the DOE International Programs Office, the SERI International Division, and the DOC International Trade Administration.

- International Solar Program Plans

A detailed solar export assistance plan should be prepared for each target solar industry segment recommended by the solar export advisory group (e.g., SHAC Active Collectors, Solar Thermal Electric, etc.) Such plans should be developed along the same lines as the "International Photovoltaic Program Plan" developed by SERI in 1979. This plan was formulated with the participation of the photovoltaics industry and individuals from other industries with experience in the export marketing and financing of U.S. products. Such plans would provide a clear focus on the unique export potentials, problems, and viable solutions which selected solar segments represent, and offer a more goal-oriented approach to successfully expanding the export market for U.S. solar products. 


\section{APPENDIX}

A. LIST OF SOLAR INDUSTRY CONTACTS

B. SELECTED BIBLIOGRAPHY 


\section{THIS PAGE}

WAS INTENTIONALLY

$\therefore \quad$ LEFT BLANK 


\section{LIST OF SOLAR INDUSTRY CONTACTS}

Photovoltaics (29 companies)

Applied Solar Energy Corp.

ARCO Solar, Inc.

C\&D Batteries

Energy Conversion Devices

General Electric

International Rectifier

Lockheed Missiles \& Space Co.

McGraw Edison

Mobil Tyco Solar Energy Corp.

Motorola, Inc., Semiconductor Division

Optical Sciences Group, Inc.

Parker McCrory Manufacturing Co.

Photon Power Inc.

Photowatt, Internationa 1

RCA

SES, Inc.

Silicon Sensors, Inc.

Solar Electric International

Solar Power Corp.

Solarex Corp.

Solec International, Inc.

Solenergy Corp.

Sollos, Inc.

Spectrolab, Inc.

SPIRE Corp.

Sun-Trac. Corp/Opto Technology

Tideland Signal Corp.

Varian Vacuum Division

Westinghouse

SHAC-Active/Collectors (54 companies)

Albuquerque Western Solar Industries

Alpha Solarco

Alten Corp.

American HCP, Inc.

American Heliothermal Corp.

American Solar King Corp.

Ametek, Inc., Power Systems Group

Bio-Energy Systems, Inc.

Calillac Marlufacluring Co.

Chicago Solar Corp.

Cole Solar Systems, Inc.

Colt, Inc.

Columbia Chase Solar Energy

Conserdyne Corp.

Fafco, Inc. 


\section{LIST OF SOLAR INDUSTRY CONTACTS (Continued)}

General Electric

General Extrusions

Grumman International

Halstead \& Mitchell

Hel iodyne, Inc.

International Solar Technologies, Inc.

Intertechnology/Solar Corp.

Jacobs-Del Solar Systems, Inc., Subsidiary of Jacobs Engineering Group

KTA Products Div., NPD Energy Systems

Lennox Industries, Inc.

LOF Solar Energy Systems

Northrup, Inc., Subsidiary of ARCO Energy Conservation, Inc.

Novan Energy, Inc.

Owens-Illinois

Paolino Energy Products

Piper Hydro, Ine.

Ramada Enerq.y Systems

Raypak, Inc.

Revere Solar \& Architectural Products

Reynolds Metals

Rom-Aire Solar Corp.

Solar Development, Ir.c.

Solar Energy Products, Inc.

Solar Energy Research Corp.

Solar Industries, Inc., (Farmingdale, NJ)

Solar Industries, Inc., (Denver, CO)

Solar Thermal Systems, Division of. Exxon

Solar Unl imited, Inc.

Solargenics, Inc.

solaron Corp.

Sunburst Solar Energy, Inc.

Sunmaster Corp.

Sunsav, Inc.

Suntec Systems, Inc.

Sunworks, Division. of Enthone, Inc.

U.S. Solar Corp.

Valmont Energy Systems

Ying Manufacturing Corp.

Znmeworks Corp.

SHAC-Active/Controls ( 11 companies)

Eaton Controls

Hawthorne Industries, Inc., Solar Energy Division

Hel iotrope General, Inc.

Honeywel1

Independent Energy

Johnson Controls

Natural Power

Rho Sigma

Richdel, Inc.

Robertshaw Controls Co.

Solar Control Corp. 


\section{LIST OF SOLAR INDUSTRY CONTACTS (Continued)}

SHAC-Active/Pumps (10 companies)

Armstrong Pumps, Inc.

Grundfos Pumps Corp.

ITT, Fluid Handling Division

Little Giant Pump Co.

March Manufacturing Co.

Milton Roy Co., Hartell Division

Myson, Inc.

Sta-Rite Industries

Taco, Inc.

Thrush Products., Inc.

SHAC-Active/Storage (8 companies)

A.0. Smith Corp.

Bradford-White Corp.

Ford Products Corp, Solar Products Division

Mor-Flo Industries

PSI Energy Systems, Inc.

Rheem/Ruud Water Heater Division

State Industries, Inc.

W.L. Jackson Manufacturing Co., Inc.

SHAC-Active/0ther Components (10 companies)

Arkla Industries

Carrier

Dow Corning

DuPont

Mueller Brass Co.

National 0lympic Solar Corp.

01 in Brass

Phelps Dodge Brass Co.

Terra-Light Inc., Subsidiary of Butler Manufacturing Co.

Weslinghouse

SHAC-Passive (8 companies)

CY/RO Industries

Energy Control Products/3M

Insul shutter

Kalwall Corp.

Martin Processing. Inc.

One Design

PSI Energy Systems, Inc.

Solar Technology Corp. 


\section{LIST OF SOLAR INDUSTRY CONTACTS (Continued)}

Wind (29 companies)

Aero Power Systems, Inc.

Alcoa

American Wind Turbine

Astral Wilcon/Wind Energy Services Co.

Bendix

Boeing

Dakota Wind \& Sun, Ltd.

Dempster Industries, Inc.

Dynergy Corp.

Enertech Corp.

General Electric

Grumman International

Hamilton Standard

Heller Aller Co.

Independent Energy Systems, Inc.

Kaman Aerospace Corp.

Kedco, Inc.

North Wind Power Co.

Pinson Enerqy Corp.

Sencenbaugh Wind Electric

Tumac Industries

Valley Industries, Aeromotor Division

W.T.G. Energy Systems, Inc .

Wadler Manufacturing Co., Inc.

Westinghouse

Winco, Division of Dyna Technology

Wind Power Systems, Inc.

Windworks, Iñc.

Zephyr Wind Dynamo Co.

Solar Thermal Electric (11 companies)

Acurex Solar Corp.

Boeing Engineering \& Construction

Foster Wheeler Solar Development Corp.

Genera 1 Atomic

McDonnel1 Douglas

Omin ium-G

Rockwell International

Solar Kinetics

Sundstrand

TRW

Thermo Electron Corp. 
Biomass (16 companies)

Advanced Combustion Systems

Anaerobic Energy Sys tems

Andco, Inc.

Atlas Systems Corp.

Bahco Systems Co.

Bio-Gas of Colorado, Inc.

C. J. Wennberg, Inc.

Combo Furnace Co.

Energy Resources Co.

Guaranty Performance Co.

Hobbs-Adams Engineering Co.

Joseph Oat Corp.

National Synthetic Fuels, Inc.

Pillard, Inc.

U.S. Alcohol Corp.

Woodex

Low-Head Hydroelectric (1 company)

All is-Cha lmers

Ocean Thermal Energy Conversion (OTEC) (3 companies)

Lockheed Missiles \& Space Co.

TRW

Westinghouse

Architects/Engineers ( 13 companies)

Bechtel

Black \& Veatch

Bridges \& Paxton

Dubin-Bloome Assoc.

The Ehrenkrantz Group

Flack \& Kurtz

Gilbert Assoc., Inc.

New Mexico Solar Energy Institute

Ralph M. Parsons Co.

Solar Design Assoc.

Syska \& Hennessy

TAMS (Tipetts-Abbett-McCarthy Stratton)

Vachon, Nix \& Associates 


\section{LIST OF SOLAR INDUSTRY CONTACTS (Continued)}

Instrumentation ( 7 companies)

Climatronics

The Eppley Laboratory, Inc.

Holl is Observatory

Li-Cor, Inc.

Matrix, Inc.

Natural Power, Inc.

Spectran Instruments

Other Services ( 2 companies)

Solar Energy Information Services (SEIS).

Solar Usage Now

Other Contacts

American Wind Energy Association

Energy Information Administration, DOE

Idaho Engineering Laboratory

International Trade Administration, DOC

Internationa 1 Trade Committee, SEIA

Muller \& Company

National Gasohol Commission

The Republic Group

Solar Business Office, State of California

Solar Energy Information Data Bank, SERI

Wnod Energy Institute 


\section{APPENDIX B}

\section{SELECTED BIBLIOGRAPHY}

Ashworth, John H.; Meunier, Richard E.; "International Development Assistance for Renewable Technologies, Current Programs and Institutional Requirements," Presented at the Annual Meeting of the International Solar Energy Society (ISES), Atlanta, Ga, May 28 - June 1, 1979, SERI/TP-51-256.

Ashworth, John, "Technology Diffusion Through Foreign Assistance: Making Renewable Energy Sources Available to the World's Poor, "Solar Energy Research Institute, Golden, Colo., Policy Sciences 11 (1980),241-261, El sevier Scientific Publishing Co., Amsterdam.

Bereny, Justin A., Survey of the Emerging Solar Industry, Solar Energy Information Services (SEIS), San Mateo, California, 1977.

Howe 11, Yvonne; Bereny, Justin A.; Engineers Guide to Solar Energy, Solar Energy Information Services (SEIS), San Mateo, California, 1979.

Illinois Institute of Natural Resources, "Illinois Solar Energy Directory," Report ILLDOE-80/01, January 1980.

Javetski, John, "A Burst of Energy in Photovoltaics," Electronics,July 19, 1979, pp. 105-121.

Jet Propulsion Laboratory, "Policy Strategies for the International Marketing of Photovoltaics," Volume I and II, Contract 955463, IIT Research Institute, August 1979.

Kelly, Henry, "Photovoltaic Power Systems: A Tour Through the Alternatives," Science, Vol. 199, 10 February 1978.

Le May, Iain, Purdy, L. R., "Alternative Energy Sources and the Developing Nations," The American Society of Mechanical Engineers, New York, N.Y., Report 78-WA-TS-3, 1978.

Lewis, Christopher W., "The Prospects for Solar Energy Use in Industry within the United Kingdom," Solar Energy, Vol. 24, pp. 47-53. Pergamon Press Ltd., Printed in Great Britain, 1980.

Lilien, Gary L., "The Diffusion of Photovoltaics: Background, Modeling, and Initial Reaction of the Agricultural-Irrigation Sector," MIT-EL-78-004, March 1978.

"The New Export Policy Works Like the 01d - Badly," Business Week, Ju1y 21, 1980.

Onyeonwu, R. 0., Univ. of Benin, Benin City, Nigeria, "Commercialization of Solar Energy Devices in Developing Countries - Problems and Prospects," Solar Energy, Vol. 22; pp. 447-449, Pergamon Press Ltd., 1979, Printed in Great Britain. 


\section{SELECTED BIBLIOGRAPHY (continued)}

"The Reindustrialization of America," Special Issue, Business Week, June 30, 1980. "Second Annual Solar Product Listing," Solar Engineering Magazine, Mid-April 1980.

Smith, Douglas V., Consultant; and Allison, Stephen V., "Micro Irrigation with Photovoltaics," MIT Energy Laboratory Report - MIT-EL-78-006, April 1978.

Smith, Douglas V., "Photovoltaic Power in Developing Countries," MIT Energy Laboratory Report, March 1977.

Solar Energy Research Institute, "Characterization and Assessment of Potential European and Japanese Competition in Photovoltaics," SERI TR-8251-1, October 1979.

Solar Energy Research Institute, "Commercial Readiness Assessment of Wind Energy Conversion Systems", SERI/TR-431-368. Apri1, 1980.

Solar Energy Research Institute, Fuel From Farms, A Guide to Small Scale Ethanol Production, Contract EG-77-C-01-4-42, February 1980.

Solar Energy Research Institute, "Impact of International Financial Institutions on Markets for Solar Energy Systems," Subcontract AM-9-8228-1, October 1979.

Solar Energy Research Institute, "International Photovoltaic Program Plan," Volume 1 and 2, SERI/TR-353-361, December 1979.

Solar Energy Research Institute, "A Review of Selected Market Studies and Techniques - Progress Report," SERI/PR-52-076, October 1978.

"Solar Products Directory," Solar Age, Aprit 1980.

State of California, Solar Business Office, "California Solar Business Directory, February 1980.

State of California, Solarcal Council, "Solar Export Survey of California Solar Firms," September 1979.

Tabors, Richard D., "The Economics of Water Lifting for Small Scale Irrigation in the Third World: Traditional and Photovoltaic Technologies, "MIT Energy Laboratory Working Paper \#MIT-EL-78-015, August 1978.

U.S. Congress/U.S. House of Representatives Hearing/ Subcommittee on Energy, Environment, Safety and Research, "Buy-Ups in the Solar Photovoltaic Industry," July 30, 1980.

U.S. Department of Commerce, "A Basic Guide to Exporting," January 1979.

U.S. Department of Commerce, Domestic and International Business Administration, "Solar Energy Equipment (Iran)," DIB-78-07-505, Trade Center, Tehran, Iran, December 1977. 
SELECTED BIBLIOGRAPHY (continued)

U.S. Department of Commerce/U.S. Department of Energy, "Proceedings of the Solar Export Issues Workshop, Bethesda, Maryland, August 12-14, 1979," October 1979.

U.S. Department of Commerce/U.S. Small Business Administration/Export-Import Bank/Overseas Private Investment Corporation, "The Small Business Market is The World."

U.S. Department of Energy, "Analysis of Smal] Business Participation in the Photovoltaic Area of Solar Technology, Contract EG-77-C-01-4055, April 1978.

U.S. Department of Energy, "Assessment of Solar Photovoltaic Industry, Markets, and Technologies," Contract EX-77-C-03-1378, 1978.

U.S. Department of Energy, "Domestic Policy Review of Solar Energy" Volume 1 and 2, TID-28830/1 and 2, October 1978.

U.S. Department of Energy, "Export Potential for Photovoltaic Systems," April 1979.

U.S. Department of Energy, "Market Definition Study of Photovoltaic Power for Remote Villages in the United States," Contract NASA CR-159800, Motorola, Inc., Phoenix, Arizona, February 1980.

U.S. Department of Energy, "Photovoltaic Power Systems Market Identification and Analysis," Volume 1 and 2, Contract EG-77-C-01-2533, November 1978.

U.S. Department of Energy, "Proceedings of the DOE/Solar Export Issues Workshop, Atlanta, Georgia, January 8-10, 1979," SERI-TR-49-186, Apri1 1979.

U.S. Department of Energy, "Solar Energy Commercialization for European Countries," Volume 1 and 2, Contracts EG-77-C-01-42.11 and EM-78-C-01-4250, December 1978.

U.S. Department of Energy, "Technical and Economic Assessment of Solar Powered Pumping for Remote Areas," Contract DE-AC04-76DP00789, Sandia Laboratories, New Mexico and Livermore, California, July 1979.

U.S. Department of Energy, "Wind Eneray Systems - Program Summary", DOE/ET-0093, December, 1978.

U.S. Department of Energy, Energy Information Administration, "Solar Collector Manufacturing Activity, July through December 1979", DOE/EIA-0174 (79/2), March. 1979.

U.S. Department of Energy, Energy Information Administration, "Wind Energy Conversion Systems Manufacturing and Sales Activity," 1976. 
U.S. Smal1 Business Administration, "Export Marketing for Smaller Firms," 3rd Edition, August 1971.

The World Bank, "A Program to Accelerate Petroleum Production in the Developing Countries," January 1979.

The World Bank, "Testing and Demonstration of Sma11-Scale Solar-Powered Pumping Systems," UNDP Project G:L0/78-004, Halcrow, Sir William, and Partners, in Association with the Intermediate Technology Development Group Ltd., December 1979. 


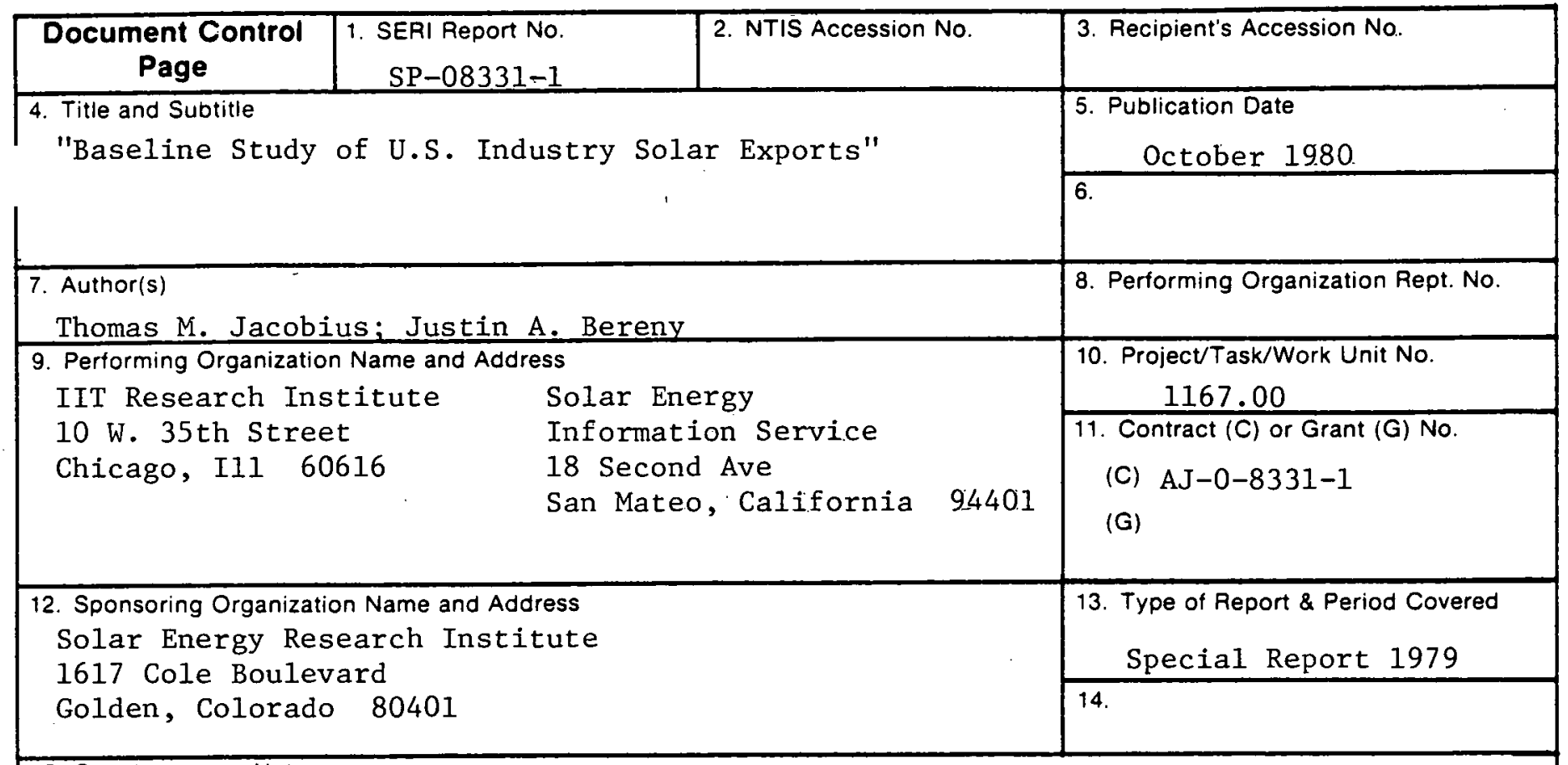

15. Supplementary Notes

Technical Monitor: Peter Thompson

16. Abstract (Limit: 200 words)

This study is a detailed aggregate profile of U.S. solar export activity in 1979 based on a survey of all segments of the solar industry. It identifies the dollar volume of exports by technology:
1. Solar heating and cooling products
$\$ 5.9$ Millions
2. Wind products
3. Photovoltaics
4. Solar thermal electric
5. OTEC, Biomass
6. Support Products \& Services
$\begin{array}{rr}\$ 1.5 & \text { Millions } \\ \$ 14.0 & \text { Millions } \\ \$ 1.1 & \text { Millions } \\ \$ \text { neg. } & \text { Millions } \\ \$ 1.0 & \text { Millions } \\ \text { \$23.5 } & \text { Millions }\end{array}$

The study offers to government and industry groups, for the first time, comprehensive information with which to formulate export goals and assistance measures based on the current realities of the solar export marketplace. Specific and aggregate recommendations which can lead to identification of realistic solar export opportunities and development of solar export markets are included.

17. Document Analysis

a. Descriptors Biomass; Exports:Q1: Low Head Hydroelectric Plants; Marketing Research:T2 Marketing:Q1; Ocean Thermal Energy Conversion; Photovoltaic Power Supplies; Solar Cooling Systems; Solar Heating Systems; Solar Industry:T1; Solar Thermal Power Plants; Surveys:Q2; Wind Power Plants; Conversion; Electronic Equipment; Energy Conversion; Energy Sources; Heating Systems; Hydroelectric Power Plants; Industry; Power Plants; Power Supplies; Renewable Energy Sources; Solar Energy Conversion

c. UC Categories $58 \mathrm{e}$

8. Availability Statement

Natinna1 Terhnical Information Service

U.S. Department of Commerce

5285 Port Royal Road

Springfield, Virgina 22161

\begin{tabular}{|c|}
\hline $\begin{array}{c}\text { 19. No. of Pages } \\
9 \dot{2}\end{array}$ \\
\hline 20. Price $\$ 6.00$
\end{tabular}

